\title{
35. MINERALOGY AND GEOCHEMISTRY OF ORE MINERALS FROM BASALTS RELATED TO SPREADING CENTERS OF THE EASTERN PACIFIC WITH SPECULATIONS ON ORE-FORMING PROCESSES
}

\author{
Ed L. Schrader ${ }^{1}$ and W. J. Furbish, Department of Geology, Duke University, Durham, North Carolina
}

\begin{abstract}
Two opaque phases, Ti-magnetite and pyrite, are ubiquitous in the basalts retrieved from the eastern Pacific on DSDP Leg 54. Additional, but minor, phases observed in reflected light include pyrrhotite, chalcopyrite, ilmenite, hematite, goethite, spinel, and amorphous manganese oxides.

The dominant mode of occurrence for the Ti-magnetite and all sulfide phases is as grains, crystals, or spheres enclosed in basalt glass or interstitial to crystalline silicates. Ti-magnetites are present mainly as skeletal crystals whose grain size appears directly proportional to the degree of undercooling of the lava. The sulfides occur generally as monomineralic or polymineralic spheres apparently separated immiscibly from the silicate melt. Sulfide veining and replacement of silicates and primary oxides takes place in several samples and suggests a secondary (e.g., hydrothermal) period of ore mineral deposition. The veins are dominantly pyrite, with very minor chalcopyrite and/or pyrrhotite in a few cases.

The samples studied and published research results support the concept of spreading centers as loci for certain types of metallogenesis. Ore bodies related to divergent plate margins may include massive sulfides, stratiform complexes, and hydrothermal manganese oxide deposits, all of which are related to the types of magmatic and secondary processes which affected the basalts recovered on Leg 54 .
\end{abstract}

\section{INTRODUCTION}

Increasing interest in the formation of ore deposits along active plate margins (Schrader et al., 1977; Bonatti et al., 1976; Keays and Scott, 1976; Rona, 1978) has stimulated research into the chemistry and petrography of opaque phases in oceanic basalts. The diverse tectonic settings drilled in the eastern Pacific on Leg 54 of the Deep Sea Drilling Project provide an unusual opportunity for the study of ore mineral genesis near oceanic spreading centers. The findings of Schrader et al. (1977), Schrader et al. (Picritic basalts etc., this volume), and the present study lead us to speculate upon the origin of mafic cumulate ores, $\mathrm{Co}-\mathrm{Ni}$ sulfide ores associated with hybrid basalts, and low-temperature Fe-Mn oxides. All of these deposits may be associated with the tectonic processes of magmatic upwelling, positioning of quasi-static axial magma reservoirs beneath ocean ridges, and the actual process of sea-floor accretion.

A variety of opaque phases occur in the basalts recovered on Leg 54. The dominant ore minerals are pyrite and Ti-magnetite. Skeletal to subhedral magnetites have a size range of $<1 \mu \mathrm{m}$ to $>100 \mu \mathrm{m}$. Pyrite occurs as disseminated sulfide globules in basaltic glass

\footnotetext{
${ }^{1}$ Present address: Department of Geology and Geography, The University of Alabama, University, Alabama.
}

and as the main component of secondary sulfide veins. Additional sulfides in the globules are pyrrhotite, chalcopyrite, and Co-Ni phases. Chalcopyrite and pyrrhotite are the only sulfides other than pyrite found in the veins. Other ore minerals in the basalts are spinel, ilmenite, hematite, and goethite. It is evident from the diverse mineralogy discovered in these basalts that a variety of magmatic, deuteric, weathering, and hydrothermal events were responsible for the formation and growth of these ore phases.

\section{PETROLOGIC AND CHEMICAL RESULTS}

Table 1 details the size, occurrence, and relative abundance of the ore minerals in the 154 samples we studied. Both shipboard and land-based opaque microscopic identifications, X-ray diffraction examinations, and electron microprobe analyses were made to obtain these data. Samples were selected from basalts from six sites cored near the East Pacific Rise crest in the vicinity of the Siqueiros fracture zone, and from two sites near the Galapagos Rift (Figure 1).

Representative electron microprobe analyses of selected silicates and other phases are presented in Table 2 . Of the analyzed phases, all of the silicates were phenocrysts or agglomerated grains (clinopyroxenes); chalcopyrite and iron oxide grains occurred as vein fillings in a silicate matrix. 
TABLE 1

Occurrences of Ore Minerals in Leg 54 Drill Holes ${ }^{\mathrm{a}}$

\begin{tabular}{lcccccccccc}
\hline $\begin{array}{c}\text { Sample } \\
\text { (Interval in cm) }\end{array}$ & \multicolumn{2}{c}{ Ti-Mt } & \multicolumn{9}{c}{ Pyrite } \\
& $<20 \mu \mathrm{m}$ & $>20 \mu \mathrm{m}$ & Spheres & Other & Cpy & Po & Il & Gt & Sp & Co-N \\
\hline Hole 420 & & & & & & & & & & \\
$13, C C, 50-57$ & C & VR & C & - & - & - & - & - & - & - \\
$14-1,0-8$ & C & - & C & VR & VR & - & - & - & - & - \\
$14-1,10-17$ & C & - & C & VR & - & - & - & VR & - & - \\
$15-1,15-19$ & C & - & VR & - & - & - & - & - & - & - \\
$15-1,22-27$ & C & - & VR & R & - & - & - & - & - & - \\
$15-1,69-72$ & C & - & R & VR & - & - & - & - & - & - \\
$16-1,2-10$ & C & - & VR & VR & - & - & VR & - & - & -
\end{tabular}

Hole 421

2-1, 12-15

2-1, 15-17

2-1, 19-24

$3-1,28-35$

3-1, $71-75$

3-1, 102-105

$3-1,115-122$

3-1, 145-148

4-1, 4-7

$4-1,32-36$

C
C
-
C
C
C
-
-
-

Hole 422

$7-1, \# 2$

$7-1, \# 4$

$7-1, \# 7 \mathrm{E}$

$7-1, \# 11$

$7-2, \# 3$

$8-5, \# 5$

$8-5, \# 14$

9-1, \#4C

$9-2, \# 6$

$9-3, \# 6 \mathrm{C}$

$9-4, \# 3 \mathrm{~B}$

9-4, \#13A

$9-5$, \#6

$10-1, \# 3$

$\begin{array}{ll}\text { C } & - \\ - & \text { C } \\ - & \text { C } \\ - & \text { C } \\ - & \text { C } \\ - & \text { C } \\ - & \text { C } \\ - & \text { C } \\ - & \text { C } \\ - & \text { C } \\ - & \text { C } \\ - & \text { C } \\ \text { C } & \text { C }\end{array}$

Hole 424

4-6, 112-116

5-1, 9-14

5-1, 31-34

5-1, 59-67

5-1, $126-129$

5-2, 90-93

$5-3,22-25$

5-4, 10-13

6-1, 29-32

6-1, 50-53

6-1, 107-110

6-1, 138-140

6-2, 32-35

6-2, $107-109$

6-3, 21-24

$7-1,0-10$

7-1, 13-15

$\begin{array}{cc}\text { C } & - \\ \text { VR } & - \\ C & - \\ \text { C } & - \\ - & C \\ - & C \\ - & \text { C } \\ - & C \\ - & C \\ \text { C } & - \\ - & C \\ - & C \\ - & C \\ - & C \\ - & C \\ \text { C } & - \\ \text { VR } & -\end{array}$

$$
\begin{array}{cccccccc}
\text { VR } & \text { R } & - & - & - & - & - & - \\
\text { VR } & \text { R } & - & - & - & - & - & - \\
- & \text { VR } & - & - & - & - & - & - \\
\text { VR } & - & - & - & - & - & - & - \\
\text { R-C } & \text { VR } & - & - & - & - & - & - \\
\text { R-C } & \text { VR } & - & - & - & - & - & - \\
\text { R-C } & \text { R } & - & - & - & - & - & - \\
\text { VR } & \text { R } & - & - & - & - & - & - \\
\text { R } & \text { R-C } & - & - & - & - & - & \text { VR } \\
\text { R } & \text { C-R } & - & - & - & - & - & \text { VR }
\end{array}
$$

$\begin{array}{cccccccc}\text { VR } & \text { R } & - & - & - & - & - & - \\ \text { R } & \text { R-C } & \text { VR } & \text { VR } & - & - & - & - \\ \text { R } & \text { R-C } & - & - & - & - & - & - \\ \text { R } & \text { R-C } & - & - & - & - & - & - \\ \text { R } & \text { R-C } & - & - & - & - & - & - \\ \text { R } & \text { R-C } & - & - & - & - & - & - \\ \text { R } & \text { C } & \text { VR } & - & - & - & - & \text { VR } \\ \text { R } & \text { C } & - & - & - & - & - & - \\ \text { R } & \text { C } & - & - & - & - & - & - \\ \text { R } & \text { R-C } & - & - & - & - & - & - \\ \text { R } & \text { R-C } & \text { VR } & - & - & - & - & - \\ \text { R } & \text { R-C } & - & - & - & - & \text { VR } & - \\ \text { R } & \text { R-C } & - & - & - & - & - & - \\ \text { VR } & \text { R } & - & - & - & - & - & -\end{array}$

Hole 424A

3,CC, 10-13

4-1, 3-5

4-1, 45-47

$\mathrm{C}$
$\mathrm{C}-\mathrm{VR}$
$\mathrm{C}$

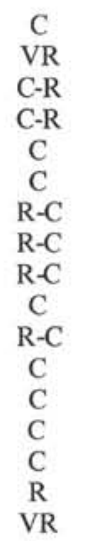

-
-
VR
$V R$
VR
VR
VR
$R$
R
VR
R
R-C
R-C
R-C
R
-
- 
TABLE 1 - Continued

\begin{tabular}{|c|c|c|c|c|c|c|c|c|c|c|}
\hline \multirow{2}{*}{$\begin{array}{c}\text { Sample } \\
\text { (Interval in } \mathrm{cm} \text { ) }\end{array}$} & \multicolumn{2}{|c|}{ Ti-Mt } & \multicolumn{2}{|c|}{ Pyrite } & \multirow[b]{2}{*}{ Cpy } & \multirow[b]{2}{*}{ Po } & \multirow[b]{2}{*}{ Il } & \multirow[b]{2}{*}{$\mathrm{Gt}$} & \multirow[b]{2}{*}{$\mathrm{Sp}$} & \multirow[b]{2}{*}{ Co-Ni } \\
\hline & $<20 \mu \mathrm{m}$ & $>20 \mu \mathrm{m}$ & Spheres & Other & & & & & & \\
\hline \multicolumn{11}{|l|}{ Hole 424B } \\
\hline $5-1,10-14$ & VR-R & - & VR & - & - & - & - & - & - & - \\
\hline $5-1,44-48$ & $\mathrm{C}$ & - & $\mathrm{R}-\mathrm{C}$ & VR & - & - & - & - & - & - \\
\hline $5-1,67-70$ & - & C & $\mathrm{R}$ & VR & - & - & - & - & - & - \\
\hline $5-1,116-119$ & C & - & VR & VR & - & - & - & VR & - & - \\
\hline $5-2,1-6$ & - & $\mathrm{C}$ & $\mathrm{R}$ & $\mathrm{R}$ & - & - & - & VR & - & - \\
\hline $5-2,52-56$ & $\mathrm{C}$ & - & $\mathrm{R}$ & VR & - & - & - & - & - & - \\
\hline $6-1,0-7$ & VR & - & - & VR & - & - & - & VR & - & - \\
\hline $6-1,110-120$ & $\mathrm{R}$ & - & - & - & - & - & - & VR & - & - \\
\hline $6-1,7-15$ & VR & - & - & VR & - & - & - & VR & - & - \\
\hline $6-1,15-23$ & $\mathrm{C}$ & - & VR & VR & - & - & - & VR & - & - \\
\hline $6-1,30-35$ & - & C & VR & VR & - & - & - & - & - & - \\
\hline $6-1,55-63$ & $\mathrm{C}$ & - & $\mathrm{C}$ & - & - & - & - & - & - & - \\
\hline $6-1,75-80$ & C & - & VR & VR & - & - & - & VR & - & - \\
\hline $6-1,95-101$ & - & $\mathrm{C}$ & VR-R & VR & - & - & - & - & - & - \\
\hline $6-1,101-110$ & C & - & $\mathrm{R}$ & - & - & - & - & - & - & - \\
\hline $6-1,138-144$ & - & $\mathrm{C}$ & $\mathrm{C}$ & - & - & - & - & VR & - & - \\
\hline \multicolumn{11}{|l|}{ Hole $424 \mathrm{C}$} \\
\hline $2-1, \# 2$ & $\mathrm{C}$ & - & $\mathrm{R}-\mathrm{C}$ & VR & - & - & - & - & - & - \\
\hline $2-1, \# 4$ & $\mathrm{C}$ & - & $\mathrm{R}$ & VR & - & - & - & VR & - & - \\
\hline $2-1, \# 6$ & VR-C & - & - & VR & - & - & - & - & - & - \\
\hline $2-1, \# 7$ & C & - & VR & VR-C & - & - & - & VR & - & - \\
\hline 3-1, \#1 & C & - & $\mathrm{C}$ & - & - & - & - & - & - & - \\
\hline $3-1, \# 2$ & - & $\mathrm{C}$ & $\mathrm{C}$ & VR & - & - & - & - & - & - \\
\hline $3-1, \# 4$ & C & - & $\mathrm{R}-\mathrm{C}$ & VR & - & - & - & - & - & - \\
\hline Hole 425 & & & & & & & & & & \\
\hline $7-1,43-47$ & $\mathrm{C}$ & - & VR & $\mathrm{R}-\mathrm{C}$ & - & - & - & - & - & - \\
\hline $7-1,81-85$ & $\mathrm{C}$ & - & $\mathrm{C}$ & VR & - & - & - & - & - & - \\
\hline $7-1,129-131$ & $\mathrm{C}$ & - & $\mathrm{C}$ & $\mathrm{R}$ & - & - & - & - & - & - \\
\hline $7-2,4-6$ & $\mathrm{C}$ & - & $\mathrm{R}$ & $\mathrm{C}$ & VR & - & - & - & - & - \\
\hline $7-2,52-54$ & - & $\mathrm{C}$ & - & VR & - & - & - & - & - & - \\
\hline $7-2,55-59$ & - & $\mathrm{C}$ & $\mathrm{R}$ & $\mathrm{R}$ & - & - & - & - & - & - \\
\hline $7-2,60-63$ & - & $\mathrm{C}$ & $\mathrm{R}$ & $\mathrm{R}-\mathrm{C}$ & - & - & - & - & - & - \\
\hline $7-2,115-118$ & - & $\mathrm{C}$ & $\mathrm{R}$ & $\mathrm{R}-\mathrm{C}$ & - & - & - & - & - & - \\
\hline $8-1,30-35$ & - & C-R & $\mathrm{R}$ & $\mathrm{R}$ & - & - & - & - & - & - \\
\hline $8-1,44-47$ & - & $\mathrm{C}$ & $\mathrm{C}$ & $\mathrm{R}$ & - & - & - & - & - & - \\
\hline $8-1,70-73$ & - & C & $\mathrm{C}$ & $\mathrm{R}$ & - & - & - & - & - & - \\
\hline $8-1,93-96$ & - & $\mathrm{C}$ & $\mathrm{R}-\mathrm{C}$ & $\mathrm{R}$ & - & - & - & - & - & - \\
\hline $8-1,105-110$ & - & C & $\mathrm{R}$ & $\mathrm{R}-\mathrm{C}$ & - & - & - & VR & - & - \\
\hline $8-1,130-134$ & - & $\mathrm{C}$ & VR & VR & - & - & - & - & - & - \\
\hline $8-1,145-148$ & - & $\mathrm{C}$ & VR & $\mathrm{R}-\mathrm{C}$ & VR & - & - & VR & - & - \\
\hline $9-1,26-29$ & - & $\mathrm{C}$ & VR & $\mathrm{R}$ & - & - & - & - & - & - \\
\hline $9-1,59-66$ & C & - & VR & VR & - & - & - & - & - & - \\
\hline $9-1,99-101$ & $\mathrm{C}$ & - & VR & VR-C & - & - & - & - & - & - \\
\hline $9-1,106-110$ & C & - & - & VR & - & - & - & - & - & - \\
\hline $9-2,67-69$ & $\mathrm{C}$ & - & - & VR & - & - & - & - & - & - \\
\hline $9-2,107-110$ & $\mathrm{C}$ & - & - & $\mathrm{R}$ & VR & - & - & VR & - & - \\
\hline $9-2,145-147$ & - & C & VR & R-C & - & - & - & - & - & - \\
\hline $9-3,3-5$ & - & C & VR & $\mathbf{R}$ & - & - & - & - & - & - \\
\hline $9-3,62-65$ & - & C & $\mathrm{R}$ & $\mathrm{R}$ & - & - & - & - & - & - \\
\hline $9-3,69-72$ & - & $\mathrm{C}$ & $\mathrm{R}$ & $\mathrm{R}$ & - & - & - & - & - & - \\
\hline Hole 427 & & & & & & & & & & \\
\hline $9-1,0-7$ & $\mathrm{C}$ & - & - & $\mathrm{R}$ & - & - & - & - & - & - \\
\hline $9-2,22-25$ & - & $\mathrm{C}$ & $\mathrm{R}$ & $\mathrm{R}-\mathrm{C}$ & VR & VR & - & VR & - & - \\
\hline $9-4,29-31$ & - & $\mathrm{C}$ & $\mathrm{R}$ & $\mathrm{R}-\mathrm{C}$ & - & - & - & - & - & - \\
\hline $9-4,137-139$ & - & $\mathrm{C}$ & $\mathrm{R}$ & R-C & - & - & - & - & - & - \\
\hline $9-5,78-80$ & - & $\mathrm{C}$ & $\mathrm{R}$ & $\mathrm{R}-\mathrm{C}$ & - & - & - & - & - & - \\
\hline $10-1,64-67$ & - & $\mathrm{C}$ & $\mathrm{R}$ & R-C & - & - & - & - & - & - \\
\hline $10-2,12-14$ & - & C & $\mathrm{R}$ & $\mathrm{R}-\mathrm{C}$ & - & - & - & - & - & - \\
\hline $10-3,102-106$ & - & $\mathrm{C}$ & $\mathrm{R}$ & R-C & - & - & - & - & - & - \\
\hline $10-4,53-55$ & - & C & $\mathrm{R}$ & $\mathrm{R}-\mathrm{C}$ & - & - & $\mathrm{C}$ & - & - & - \\
\hline $11-1,27-30$ & - & $\mathrm{C}$ & $\mathrm{R}$ & $\mathrm{R}-\mathrm{C}$ & - & - & - & - & - & - \\
\hline $11-1,47-49$ & C & - & VR & VR & - & - & - & VR & - & - \\
\hline
\end{tabular}


TABLE 1 - Continued

\begin{tabular}{|c|c|c|c|c|c|c|c|c|c|c|}
\hline \multirow{2}{*}{$\begin{array}{c}\text { Sample } \\
\text { (Interval in } \mathrm{cm} \text { ) }\end{array}$} & \multicolumn{2}{|c|}{ Ti-Mt } & \multicolumn{2}{|c|}{ Pyrite } & \multirow[b]{2}{*}{ Cpy } & \multirow[b]{2}{*}{ Po } & \multirow[b]{2}{*}{ Il } & \multirow[b]{2}{*}{$\mathrm{Gt}$} & \multirow[b]{2}{*}{$\mathrm{Sp}$} & \multirow[b]{2}{*}{$\mathrm{Co}-\mathrm{I}$} \\
\hline & $<20 \mu \mathrm{m}$ & $>20 \mu \mathrm{m}$ & Spheres & Other & & & & & & \\
\hline \multicolumn{11}{|l|}{ Hole 428} \\
\hline $5-3,123-126$ & - & $\mathrm{C}$ & $\mathrm{R}$ & - & - & - & - & - & - & - \\
\hline $5-4,15-18$ & C & - & $\mathrm{C}$ & - & - & - & - & - & - & - \\
\hline $5-4,36-39$ & - & $\mathrm{C}$ & $\mathrm{C}$ & - & - & - & - & - & - & - \\
\hline $5-4,81-84$ & - & $\mathrm{C}$ & $\mathrm{R}$ & - & $-\cdot$ & - & - & - & - & - \\
\hline $6-1,18-21$ & - & $\mathrm{C}$ & $\mathrm{R}$ & - & - & - & - & - & - & - \\
\hline $6-1,74-79$ & - & $\mathrm{C}$ & $\mathrm{C}$ & - & - & - & - & - & - & - \\
\hline $6-1,127-130$ & - & $\mathrm{C}$ & C & - & - & - & - & - & - & - \\
\hline $6-2,10-12$ & - & $\mathrm{C}$ & $\mathrm{R}$ & - & - & - & - & - & - & - \\
\hline $6-2,116-118$ & $\mathrm{R}$ & - & VR & - & - & - & - & $\mathrm{R}$ & - & - \\
\hline
\end{tabular}

\section{Hole 428A}

$1-1,21-23$

$1-1,92-94$

1-2, 4-7

$1-2,31-32$

1-3, $65-68$

$1-4,2-4$

$1-4,40-43$

$1-4,70-72$

$2-1,27-30$

2-1, 85-87

3-1, 20-23

3-1, 134-137

4-1, 50-53

4-1, 114-117

5-1, 21-24

5-1, 115-11 8

$5-2,12-15$

5-2, 93-95

5-2, 114-117

5-3, 31-34

$5-3,123-126$

$5-4,89-92$

6-1, 52-53

6-1, 100-103

7-2, 6-9

$7-2,147-150$

R-C
VR
R-C
-
-
$-\bar{R}$
-
$-\bar{C}$
C
-
-
-
-
-
-
-
-
-
-
-
-
-
-
VR

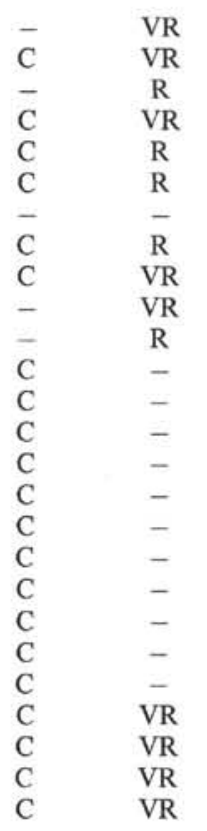

$\begin{array}{ccccccc}\mathrm{VR} & - & - & - & - & - & - \\ \mathrm{R} & - & - & - & - & - & - \\ - & - & - & - & - & - & - \\ \mathrm{R} & - & - & - & - & - & - \\ \mathrm{R} & - & - & - & - & - & - \\ - & - & - & - & - & - & - \\ - & - & - & - & - & - & - \\ \mathrm{R} & - & - & - & - & - & - \\ \mathrm{R}-\mathrm{C} & - & - & - & - & - & - \\ \mathrm{R} & - & - & - & \mathrm{R}-\mathrm{C} & - & - \\ - & - & - & - & - & - & - \\ \mathrm{R}-\mathrm{C} & - & - & - & - & - & - \\ \mathrm{R}-\mathrm{C} & - & - & - & - & - & - \\ \mathrm{C} & - & - & \mathrm{VR} & \mathrm{VR} & - & - \\ \mathrm{C} & - & - & - & - & - & - \\ \mathrm{C} & \mathrm{VR} & - & - & - & - & - \\ \mathrm{C} & \mathrm{VR} & \mathrm{VR} & - & - & - & - \\ \mathrm{C} & - & - & - & - & - & - \\ \mathrm{C} & - & - & - & - & - & - \\ \mathrm{C} & - & - & - & - & - & - \\ \mathrm{R} & - & - & - & - & - & - \\ \mathrm{R} & - & \text { VR } & - & - & - & - \\ \mathrm{C} & - & \text { VR } & - & - & - & - \\ \mathrm{R} & - & - & - & - & - & - \\ - & - & \text { VR } & \text { VR } & - & - & - \\ \mathrm{C} & - & \text { VR } & \text { VR } & - & - & - \\ & & & & & & \end{array}$

Hole 429A

\begin{tabular}{|c|c|c|c|c|c|c|c|c|c|c|}
\hline $1-1,60-63$ & C & - & VR & $\mathrm{R}$ & - & - & - & $\mathrm{R}-\mathrm{C}$ & - & - \\
\hline $2-1,41-44$ & $\mathrm{C}$ & - & VR & - & - & - & - & C & - & - \\
\hline $2-1,125-128$ & $\mathrm{C}$ & - & VR & _- & - & - & - & - & - & - \\
\hline $3-1,103-105$ & - & $\mathrm{C}$ & $\mathrm{C}$ & - & - & - & - & - & - & - \\
\hline $3-1,123-125$ & - & $\mathrm{C}$ & $\mathrm{C}$ & - & - & - & - & - & - & - \\
\hline $3-1,128-130$ & - & $\mathrm{C}$ & C & - & - & - & - & - & - & - \\
\hline $2-1,9-11$ & $\mathrm{R}-\mathrm{C}$ & - & VR & - & - & - & - & $\mathrm{R}-\mathrm{C}$ & VR & - \\
\hline $2-1,88-90$ & $\mathrm{C}$ & - & - & - & - & - & - & $\mathrm{R}$ & - & - \\
\hline $2-2,9-11$ & $\mathrm{C}$ & - & VR & VR & - & - & - & R-VR & - & - \\
\hline
\end{tabular}

Note:

$\mathrm{C}=$ common $(>2 \%)$.

$\mathrm{R}=$ rare $(<2 \%)$.

$\mathrm{VR}=$ very $\operatorname{rare}(<1 \%)$.

$\mathrm{Ti}-\mathrm{Mt}=$ titanium magnetite

Cpy $=$ chalcopyrite .

Po $=$ pyrrhotite.

Il = ilmenite.

$\mathrm{Gt}=$ goethite and amorphous, hydrated iron oxides.

$\mathrm{Sp}=$ spinel.

$\mathrm{Co}-\mathrm{Ni}=$ cobalt and nickel sulfide phases mineralogically indistinguishable.

${ }^{\mathrm{a}}$ See Initial Core Descriptions for further information on rock types and grain sizes of silicates. 


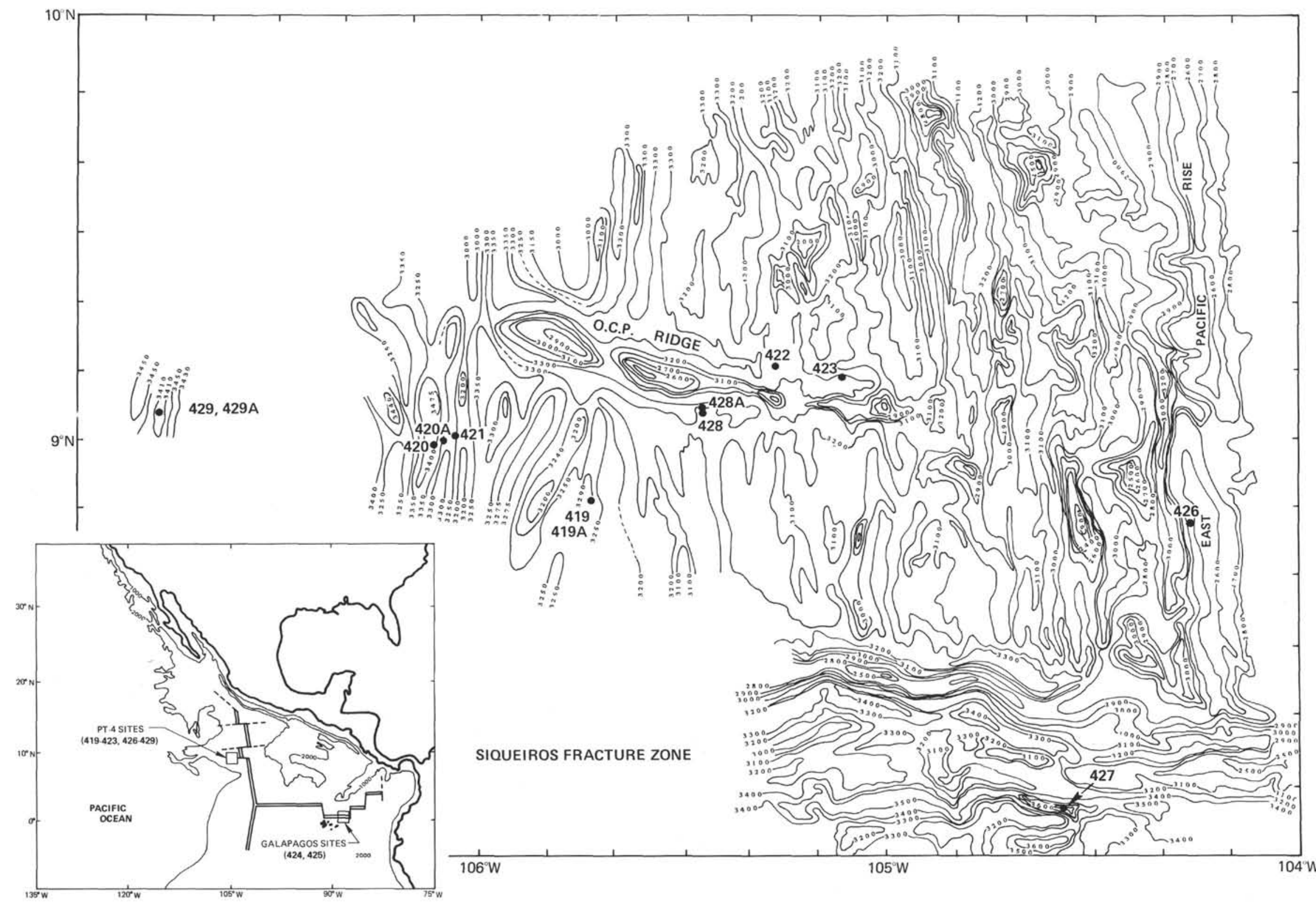

Figure 1. Location of Deep Sea Drilling Project for Leg 54. 
TABLE 2

Microprobe Analysis Data (wt. \%)

for Silicates and Selected Other Phases

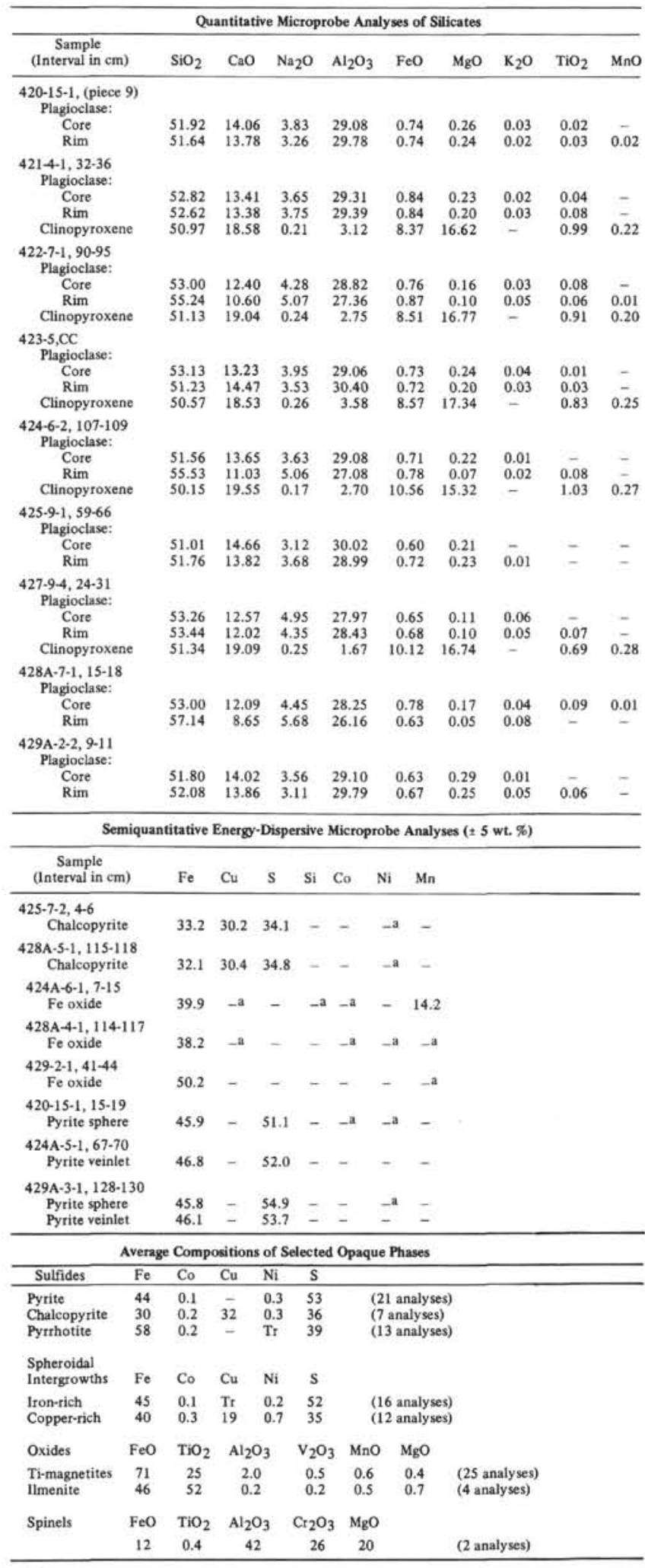

${ }^{\mathrm{a}}$ Element present but comprises less than $5 \mathrm{wt}$.\%.
Of the minerals with average compositions in Table 2 , ilmenite and pyrite compositions are nearly stoichiometric; the pyrrhotites fluctuate only slightly in iron content; and the Ti-magnetites have a representative composition similar to that reported by Ade-Hall et al. (1976). Co-Ni phases (similar to those described by Keays and Scott, 1976) were analyzed as well; their small size, however, prevented obtaining meaningful quantitative data, and in all cases the surrounding pyrite (or pyrrhotite) was also excited by the electron beam.

$\mathrm{CaO}$ and $\mathrm{Na}_{2} \mathrm{O}$ values of the feldspars listed in Table 2 confine most of these phenocrysts to compositions between $\mathrm{An}_{60}$ and $\mathrm{An}_{70}$. The plagioclase phenocrysts are richer in $\mathrm{SiO}_{2}$ and $\mathrm{NaO}_{2}$ than those reported in picrites from the Siqueiros fracture zone (see Schrader et al., this volume). Iron oxide compositions are similar to those reported by Bonatti et al. (1976), but are lower in copper. The trace amounts of nickel in the chalcopyrite may reflect residual concentrations of this metal in the hydrothermal fluids derived from magmatic crystallization. However, since the chalcopyrite-pyrite vein in which this material is found is of yet undetermined origin, the nickel could also represent leaching of underlying basalts by chemically active ascending solutions (see Bonatti, 1978).

It may be fortuitous that the copper-containing iron oxide (Sample 428A, 4-1, 114-117 cm) stratigraphically is within 10 meters of a section containing chalcopyrite. However, the oxidation (hydrothermal or deuteric) of the copper-containing portions of overlying basalt may have released metallic ions into solution which were fixed in iron oxide fracture fillings below. Although not directly correlative, Bonatti et al. (1976) proposed oxidation of $\mathrm{FeCuS}_{2}$ as a mechanism for the formation of copper-rich iron hydroxides.

\section{Hole Descriptions}

In this section the mineralogy of each drill hole is summarized and a general description of the occurrence and chemistry of each of the minerals is provided.

\section{Holes 420 and 420A}

Opaque minerals generally constitute up to 2 per cent of each sample. Four opaque phases were identified: Timagnetite, ilmenite, pyrite, and chalcopyrite. Skeletal to anhedral Ti-magnetite is by far the most abundant opaque phase, with the ilmenite occurring as exsolution lamellae in only a few grains. Pyrite occurs in two morphologies - as discrete sulphide spheres floating in a glassy matrix, and as irregular globules associated with the oxide phases and smectite. The occurrence of pyrite and smectite which rim the vesicles (Figure 2) may be indicative of deuteric alteration. Chalcopyrite occurs as an additional phase in two of the pyrite spheres.

\section{Hole 421}

There are two. dominant opaque minerals in the basalts of Hole 421: Ti-magnetite and pyrite. The oxide 


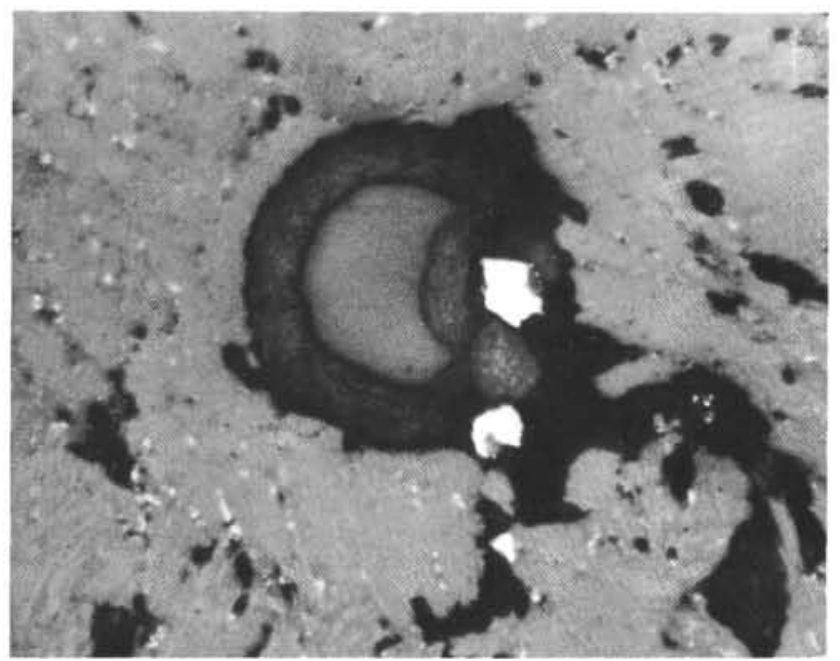

Figure 2. Vesicle rimmed by pyrite and smectite in finegrained basalt. Sample 420-15-1 (Piece 9); reflected light; $\times 16$.

is much more abundant than the sulfide, constituting over 90 volume per cent of the opaque portions in all rocks. The Ti-magnetites are skeletal to anhedral and generally are less than $20 \mu \mathrm{m}$ in diameter. The overall abundance of opaques does not exceed 2 to 3 per cent in any sample and is never less than 1 per cent. The sulfide has two distinct morphologies; (1) spheroidal and (2) irregular masses. The irregular masses of sulfide accumulations are either associated with the Ti-magnetites or agglomerated around vesicles. The sulfide spheres contain cobalt-nickel phases as exsolved lamellae in two samples.

\section{Hole 422}

In general, the opaques are continuous in mineralogy, morphology and relative abundance throughout this hole. The overall grain size of the Ti-magnetite is large, the crystals having an average diameter of about 60 to $80 \mu \mathrm{m}$; some of the larger skeletal Ti-magnetite even approach $150 \mu \mathrm{m}$ in diameter. The oxide morphology is skeletal-subhedral to skeletal-euhedral (Figure 3). No exsolved ilmenite is present. Sulfides are more common than at Site 420 and Hole 421; they are dominantly pyrite with cobalt- and nickel-rich phases as exsolution products in smaller (5 to $10-\mu \mathrm{m}$ ) sulfide spheres. The larger pyrite masses occur either as an apparent replacement of feldspars or as the final product of crystallization; they are interstitial to the feldspars (Figure 4) and clinopyroxene. The grain size of the opaques increases towards the middle of the sections, with Samples 422-8-5 (Piece 14) and 422-9-1 (Piece 4C) being the coarsest. Sulfide abundance also increases with increasing grain size. These factors indicate a closed or partially closed system in which volatiles were retained and cooling was relatively slow. One specimen [Sample 422-9-4 (Piece $13 \mathrm{~A})$ ] contained a very few small chromium spinels adjacent to plagioclase crystals that were included in magnetites. Sample 422-10-1 (Piece 3) is not at all similar to the rest of the rocks, and appears almost identical in

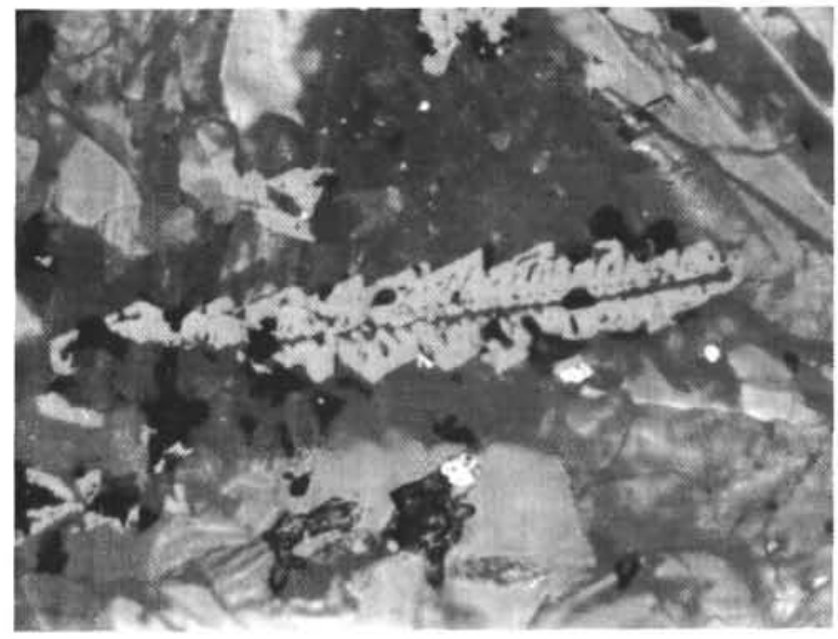

Figure 3. Stacked, twinned tetrahedra of skeletal Timagnetite with blebs of anhedral pyrite. Sample 4227-2 (Piece 3); reflected light; $\times 8$.

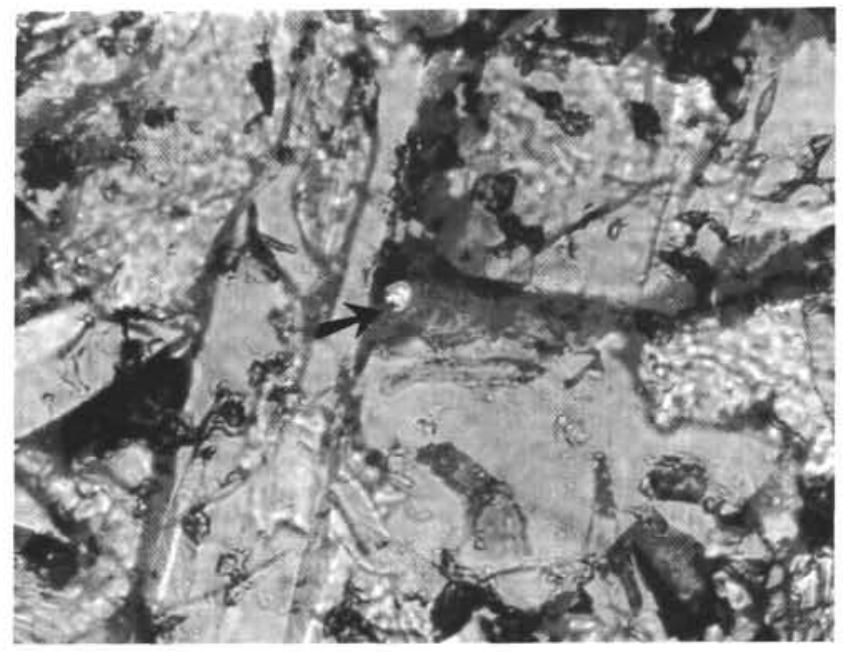

Figure 4. Pyrite sphere in glass interstitial to feldspar laths. Sample 422-7-1 (Piece 11); reflected and transmitted light; $\times 16$.

opaque abundance and morphology to the samples from Site 420 and Hole 421.

\section{Hole 424}

The ore minerals of this hole are dominantly skeletal, titanium-rich magnetites (20 to $200 \mu \mathrm{m}$ ) (Figure 5) and spheroidal pyrite masses (5 to $50 \mu \mathrm{m}$ ) (Figure 5). Pyrrhotite was identified in sulfide spheres of two samples. The overall size of the opaques at Hole 424 is much larger than at previous holes and than in other holes at Site 424, except for two specimens, Samples 424-4-6, $112-116 \mathrm{~cm}$, and $424-7-1,13-15 \mathrm{~cm}$. These two rocks are primarily glass; the opaques are very small ( 1 to $2 \mu \mathrm{m}$ ) and constitute less than 0.5 per cent of the rocks, as against 6 to 12 per cent of the other samples. The generally large grain size apparently reflects the fairly massive nature of the cooling units recovered. 


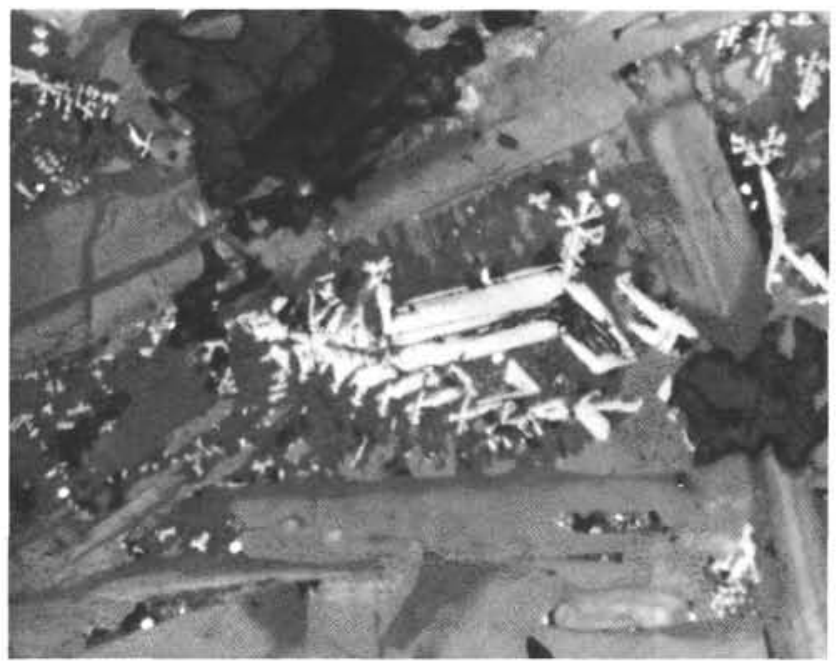

Figure 5. Rectilinear arrangement of skeletal Ti-magnetite crystals. Sample 424-5-1, 31-34 cm; reflected light; $\times 16$.

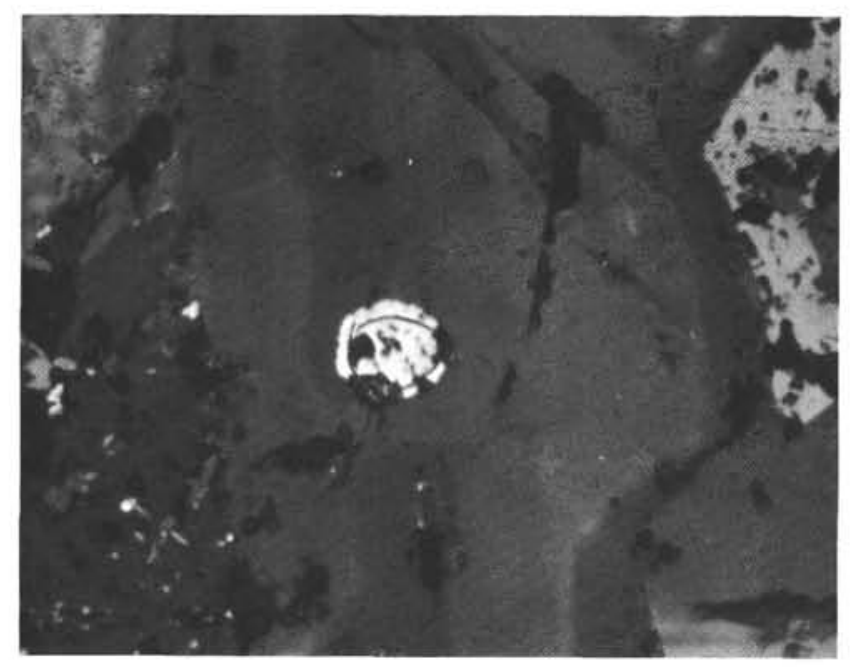

Figure 6. Chalcopyrite rind on pyrite-pyrrhotite sphere. Sample 424-6-1, 138-140 cm; reflected light; $\times 16$. Contact is highlighted on photograph.

Sulfides are larger and generally more abundant in these samples than in the rocks from Sites 420 through 422 , indicating that the cooling history of the Hole 424 rocks was such that volatiles were retained and sufficient time for crystal growth was available. Thus, the cooling was probably more gradual than for the aphyric basalts and, possibly, the restraining pressures were greater.

The opaques are interstitial to the silicates, and must be considered to have crystallized last; however, two stages of opaque crystallization can be seen. The larger magnetites and sulfides are generally not associated with glass, and are concentrated along plagioclase/clinopyroxene boundaries. Smaller (5 to $10-\mu \mathrm{m}$ ) magnetites are apparent in the rare residual pockets of glass. Addi- tional evidence for two cycles of opaque formation is derived from the following textural relationships. The larger magnetites have sulfide rims, and evidently crystallized prior to the pyrites (Figure 7); however, when sulfide spheres are adjacent to glassy sections, the pyrite is rimmed with fine-grained Ti-magnetite (Figure 8) of the size generation found in the glass. Also, larger magnetites often are accompanied by sulfide spheres flattened against them (Figure 9). The implication is that the sulfide was still liquid after the magnetite crystallized. Thus, Ti-magnetite can be seen to have crystallized at two discrete intervals relative to the sulfides.

\section{Holes 424 A, B, and C}

The ore minerals in these holes are identical, texturally and mineralogically. The basalts cored here are either portions of small pillows or thin flows. The Ti-magnetites are skeletal to anhedral in habit and generally are less than $20 \mu \mathrm{m}$ in diameter. Smaller grains of anhedral Ti-magnetite constitute the only opaque in the glassy, aphyric samples from these locations. Sulfides occur as spheres and as irregular masses in the more crystalline samples. The larger sulfide masses are anhedral to subhedral crystal groups associated with patches of the groundmass which has been altered to a layer-lattice silicate. This same assemblage also fills vesicles. Amorphous iron oxyhydroxides are often associated with these vesicle fillings. This hydrated phase has crystallized to hematite in several cases (Figure 10). The restricted occurrence of larger pyrite grains to altered areas may imply a hydrothermal origin for this form of the sulfide.

Pyrite spheres are common and range from 1 to 10 $\mu \mathrm{m}$ in size. Many of these spheres were slightly deformed as they adhered to the solid Ti-magnetites during cooling as at Site 424. Often, one side of a sphere appears to have been flattened against an already crystallized magnetite.

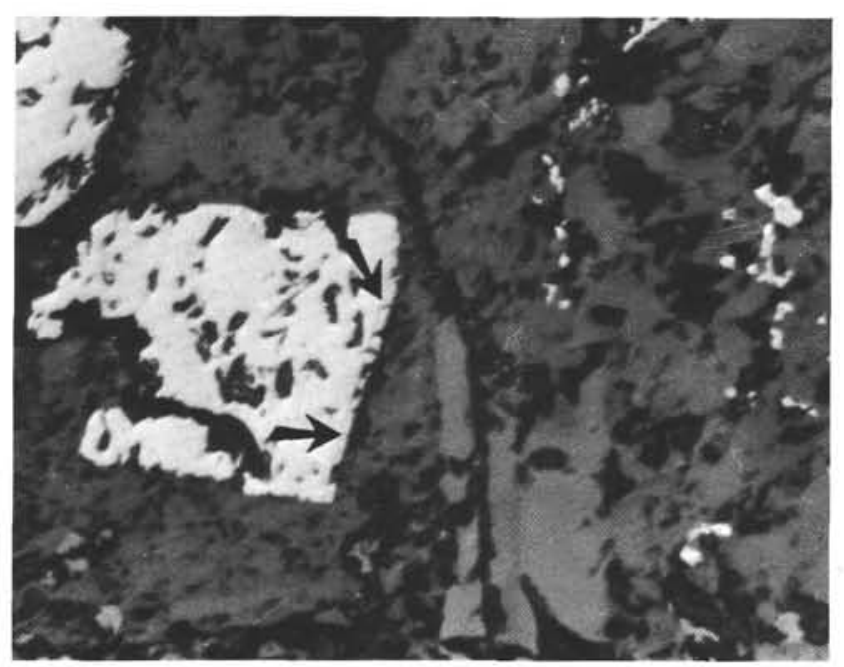

Figure 7. Subhedral Ti-magnetite with pyrite rim (indicated by arrows). Sample 424-2-6, 112-116 cm; reflected light; $\times 16$. 


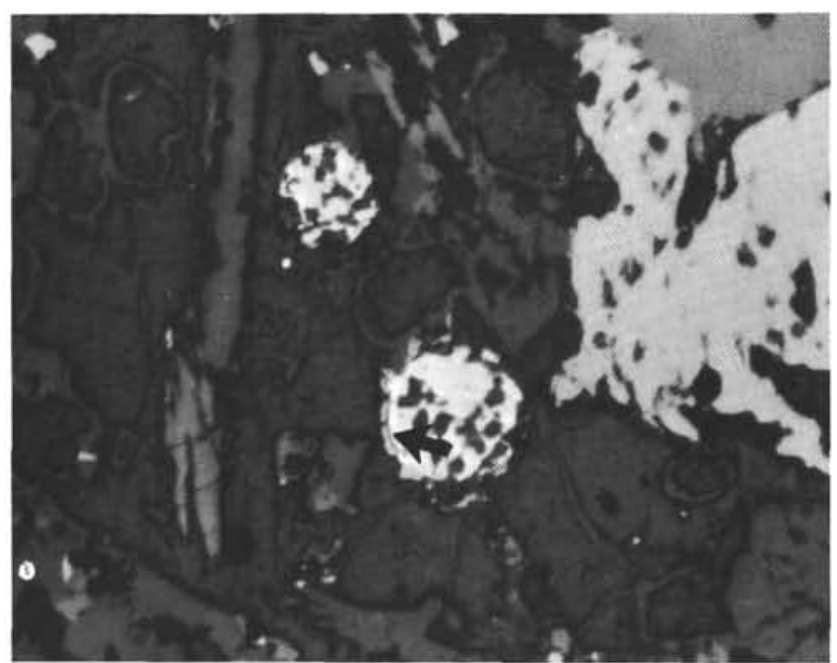

Figure 8. Two sulfide spheres. Larger sphere is pyrite rimmed by Ti-magnetite; smaller, unrimmed sphere is pyrrhotite. Sample 424-6-2, 32-35 cm; reflected light; $\times 16$. Arrow indicates rim.

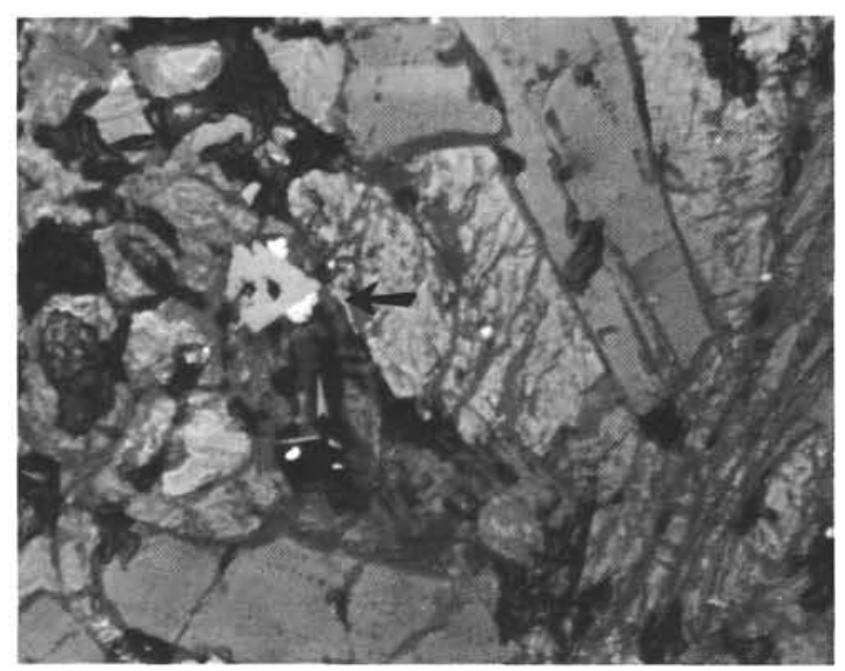

Figure 9. Pyrite spheres flattened against subhedral Timagnetite. Both opaque phases occur in interstitial glass. Sample 424-4-6, 112-116 cm; reflected light; $\times 16$.

\section{Hole 425}

The ore minerals found at this hole are of two origins - primary magmatic and hydrothermal. The primary minerals comprise Ti-magnetite and sulfide spheres. The hydrothermal minerals are pyrite and chalcopyrite. These exogenetic sulfides reside in veins (Figure 11), fracture fillings, and subhedral masses (Figure 12) that cross-cut crystalline and glassy components of the basalt. The modes of sulfide emplacement include void filling and direct replacement of the primary magmatic constituents. Where a veinlet crosses through a large magnetite crystal, the sulfide has replaced the oxide. Thus, $\mathrm{Fe}^{+3}$ has been reduced in the presence of some hydrothermal catalyst, probably hydrogen sulfide.

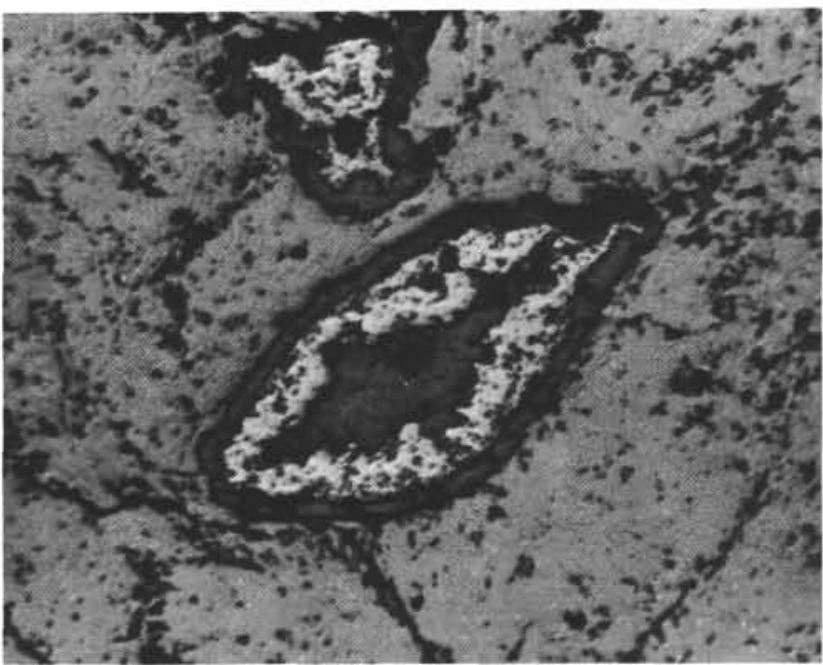

Figure 10. Vesicles filled with smectite cores, hematite intermediate zones, and amorphous $\mathrm{Fe}$ oxide outermost rinds. Sample 424B-6-1 (Piece 16); reflected light; $\times 8$.

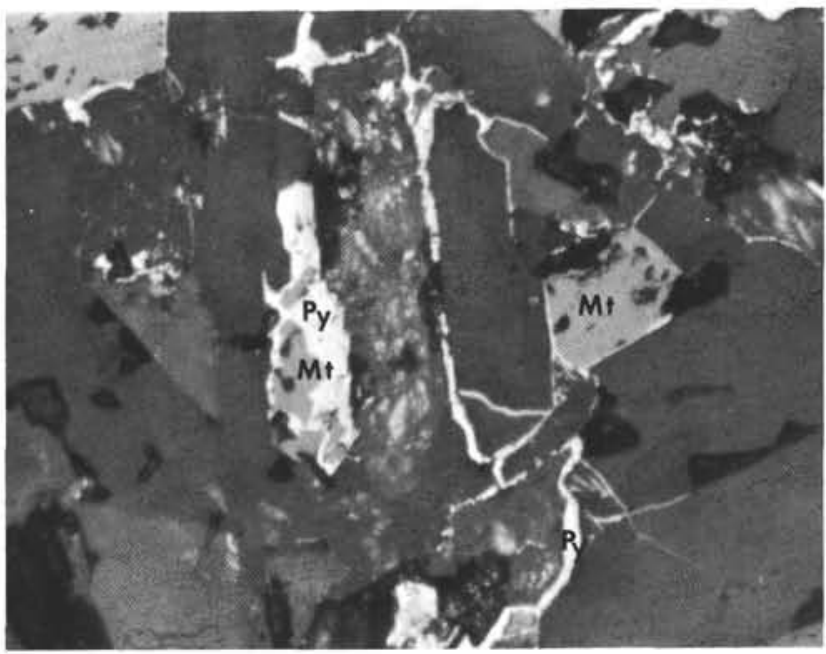

Figure 11. Pyrite veining silicates and replacing magnetite. Sample 425-9-2 (Piece 16); reflected light; $\times 16$. $P y=$ pyrite, $M t=$ magnetite.

Some secondary iron oxides and clay minerals also occur in these veins.

Ti-magnetite dominates the primary ore minerals. The sizes of these skeletal crystals range from $1 \mu \mathrm{m}$ in Sample 425-9-1, 106-110 cm (Piece 15) to over $35 \mu \mathrm{m}$ in Samples 425-8-1, 44-46 cm (Piece 6) and 425-9-1, 126$129 \mathrm{~cm}$ (Piece 5). The oxide phases generally comprise 85 to 90 per cent of the opaques; the latter generally constitute from 3 to 7 per cent of the samples.

From textural criteria, this general paragenetic sequence can be established:

Magnetite $\rightarrow$ magmatic pyrite $\rightarrow$ hydrothermal pyrite and chalcopyrite $\rightarrow$ iron oxides

The relative volumes of the chalcopyrite and iron oxides are subordinate to the volume of the other hydrothermal phase, pyrite. 


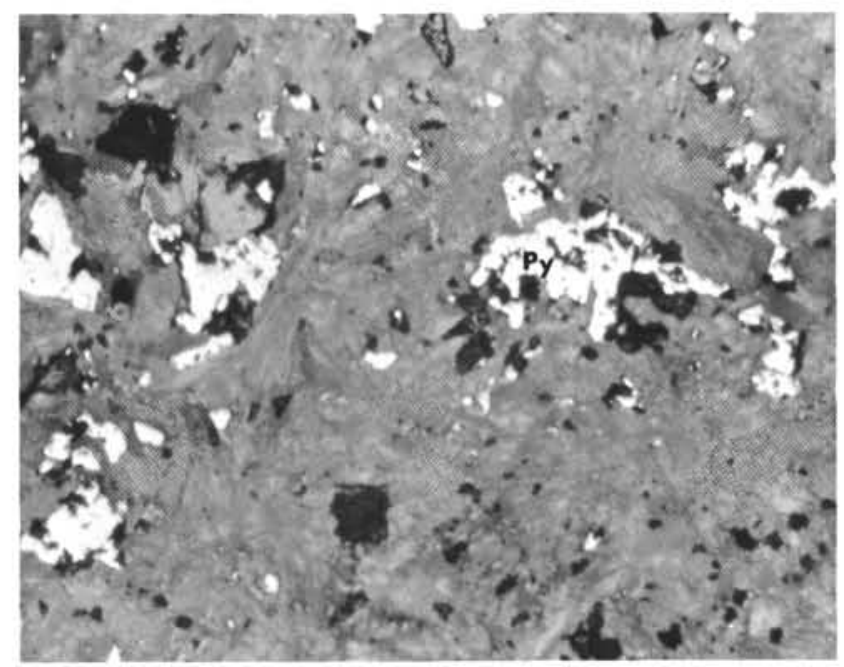

Figure 12. Subhedral to anhedral pyrite replacing silicate glass. Sample 425-8-1 (Piece 12); reflected light; $\times 16$. Py $=$ pyrite.

\section{Hole 427}

This hole yielded basaltic samples with the most diverse opaque mineralogy retrieved on Leg 54. As usual, skeletal (anhedral to subhedral) Ti-magnetite dominates the opaques in total volume. These oxides comprise about 90 to 95 per cent of the opaques in any given sample, while opaques generally make up between 5 and 10 per cent of an entire sample. Except for Samples 427-9-1, 0-7 cm (Piece 1) and 427-11-1, 47-49 $\mathrm{cm}$ (Piece 4), the Ti-magnetites are large, with crystals averaging 30 to $40 \mu \mathrm{m}$ in diameter. The Ti-magnetites are pervasively fresh in all specimens but one, Sample 427-10-4, 53-55 cm (Piece 1E). In this rock, ilmenite has exsolved from the granular, anhedral Ti-magnetite crystals, probably as a result of deuteric oxidation-alteration (Figure 13). The ilmenite laths are from 1 to $3 \mu \mathrm{m}$ wide and may reach lengths of over $20 \mu \mathrm{m}$. These laths generally are well-spaced and parallel, never abundant enough to form the rectilinear trellis pattern seen in many basalts.

Vesicles in many of the samples are filled with calcite, iron oxides (goethite), pyrite, and Ti-magnetite (Figure 14). At this time, the origin of the vesicle fillings is undetermined but could be either deuteric or hydrothermal. Pyrrhotite occurs as an exsolution product in pyrite lying along the vesicle walls. The paragenesis of these fillings is texturally determinable as:

Ti-magnetite $\rightarrow$ pyrite and pyrrhotite $\rightarrow$ calcite (fans) $\rightarrow$ calcite (drusy) $\rightarrow$ calcite (mosaics) $\rightarrow$ goethite.

The goethite appears simply to be an oxidation product of the earlier produced iron-bearing species. Additionally, sulfide veining of silicates occurs as at Hole 425 (Figure 15).

As in previously sampled areas, grain size of the opaques was proportional to crystallinity of the rock and overall grain size of the silicate phases. The coarsest opaques were near the middle of the hole. Very fine grained opaques were observed in the sample taken just above the base of the hole.

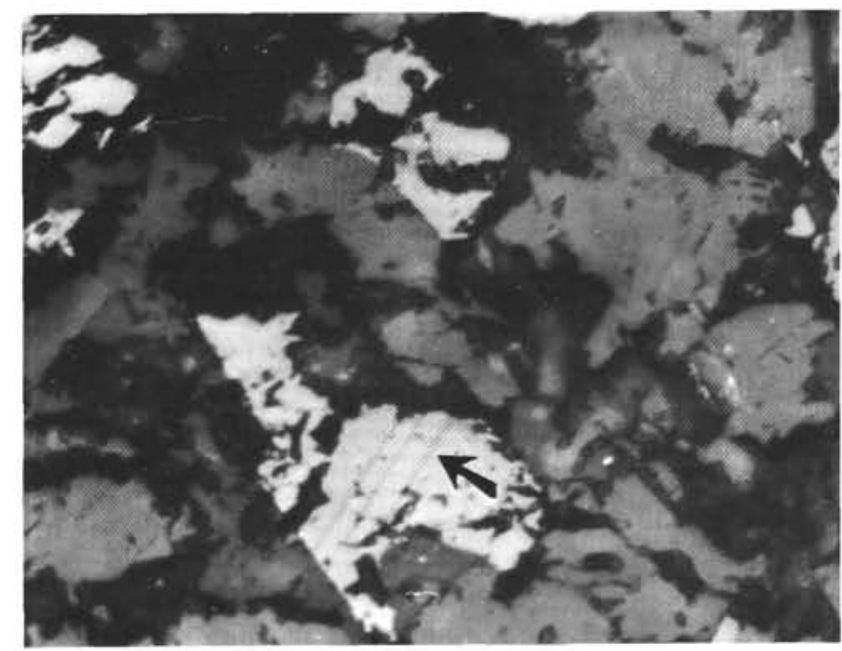

Figure 13. Ilmenite lamellae in Ti-magnetite. Sample 427-10-4, 53-55 cm; reflected light; $\times 16$; arrow indicates ilmenite.

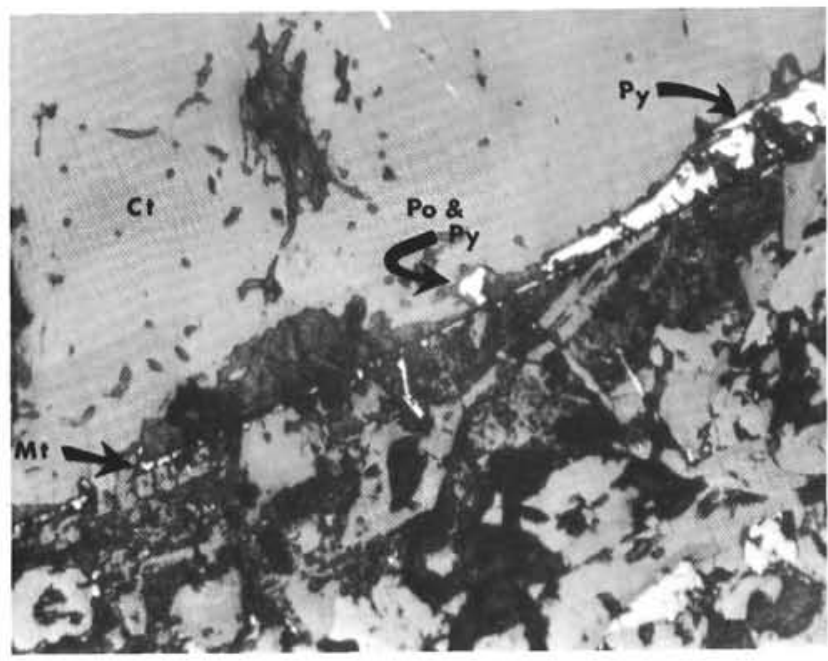

Figure 14. Ti-magnetite, pyrite, and pyrrhotite rim calcite filled vesicle. Sample 427-9-2, 22-25 cm reflected and transmitted light $\times 8 ; M t=$ Ti-magnetite; $P o=$ pyrrhotite; $P y=$ pyrite; $C t=$ calcite.

\section{Holes 428 and $428 \mathrm{~A}$}

The oxide and sulfide mineralogy of these holes is nearly identical. Large Ti-magnetites $>20 \mu$ m dominate the opaques volumetrically (Figure 16 and Figure 17); however, pyrites are common as spheres, individual subhedral grains, and as veins in Hole 428A. The sulfide veins also contain chalcopyrite. Pyrrhotite is common as an exsolution product in a few of the larger sulfide spheres in Hole 428A.

Pockets of silicate glass, now altered to a clay, are accompanied by subhedral pyrite and oxidized Ti-magnetite (Figure 18). It is possible that iron derived from the reaction of the magnetite with hydrothermal solutions, rich in $\mathrm{SO}_{4}{ }^{-2}$, could be the source of such pyrite. A hypothetical reaction is:

$$
\mathrm{Fe}_{3} \mathrm{O}_{4}+2\left(\mathrm{SO}_{4}^{-2}\right)=2(\mathrm{FeOOH})+\mathrm{FeS}_{2}+2 \mathrm{O}_{2} \text {. }
$$




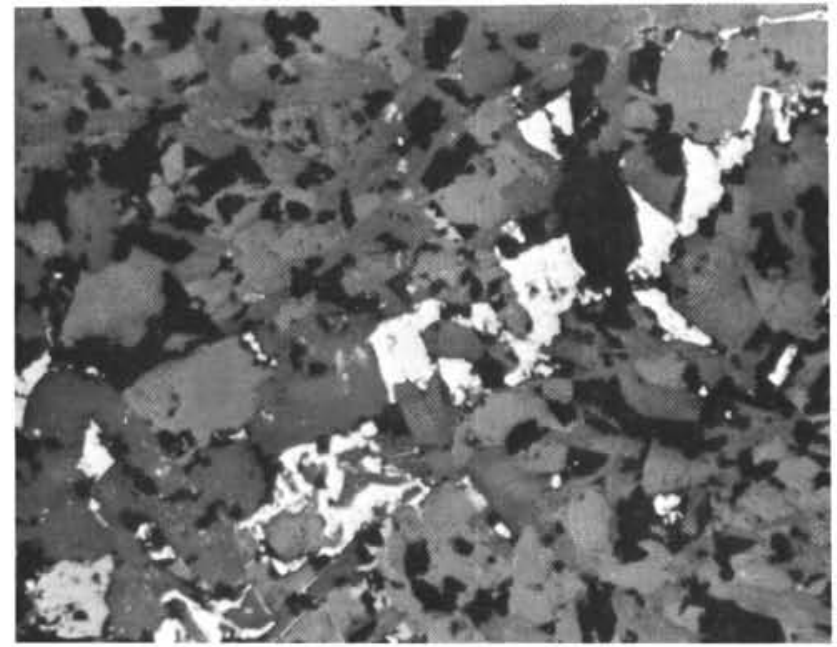

Figure 15. Pyrite veining and replacing silicate glass. Sample 427-9-4, 29-31 cm; reflected light; $\times 8$.

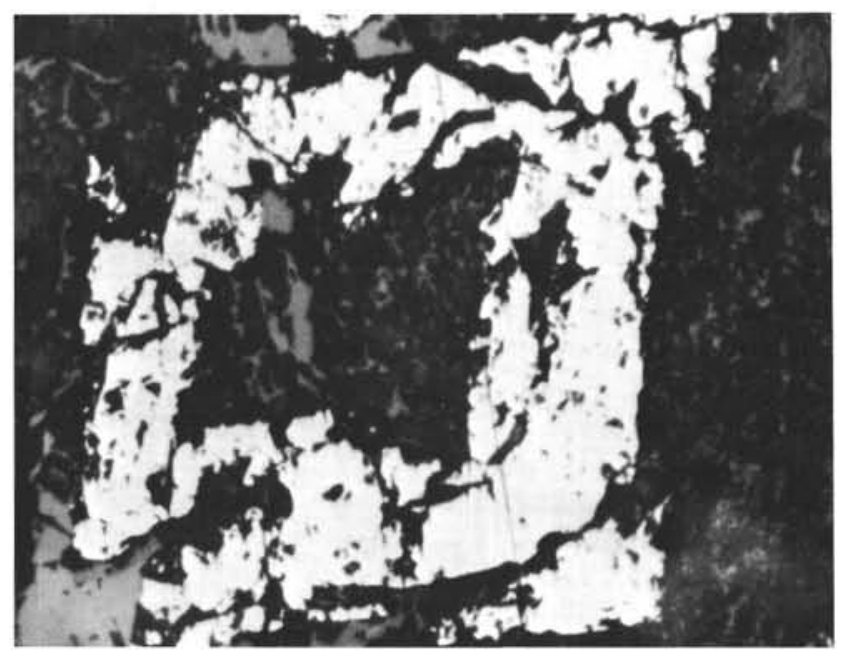

Figure 16. Large, unaltered skeletal Ti-magnetite. Sample 428A-5-1, 115-118 cm; reflected light; $\times 8$.

Although it might seem unlikely that free oxygen is present during the formation of pyrite in this environment, iron oxides and pyrite appear to have been deposited contemporaneously in the areas of silicate alteration. Whether theoretically favorable or not, a natural mechanism must exist for the coprecipitation of these species.

The authors have observed several sulfide vein deposits on lands that have obviously undergone coprecipitation of pyrite and iron oxides, both during orogenesis and subsequent weathering (Schrader and Furbish, 1976).

\section{Hole 429A}

Sulfide spheres are more common in this hole than at many of the previous holes; however, no multiplicity of

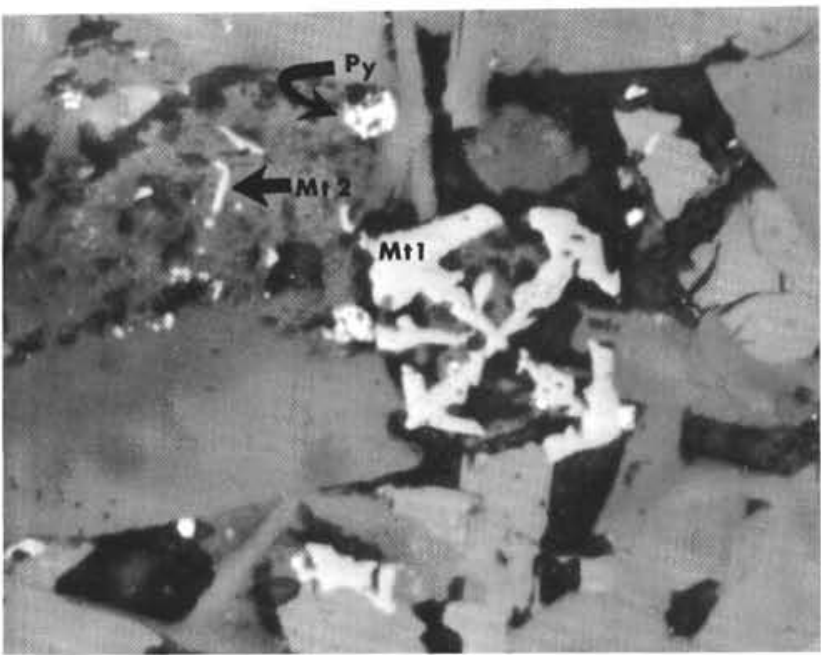

Figure 17. Skeletal Ti-magnetite in interstitial glass. Also sulfide spheres and second-generation Ti-magnetite in glass. Sample 428-5-4, $15-18 \mathrm{~cm}$, reflected and transmitted light; $\times 16 . \mathrm{Mtl}=$ first generation $\mathrm{Ti}$ magnetites; $P y=$ Py sphere; $M t 2=$ second generation Ti-magnetite.

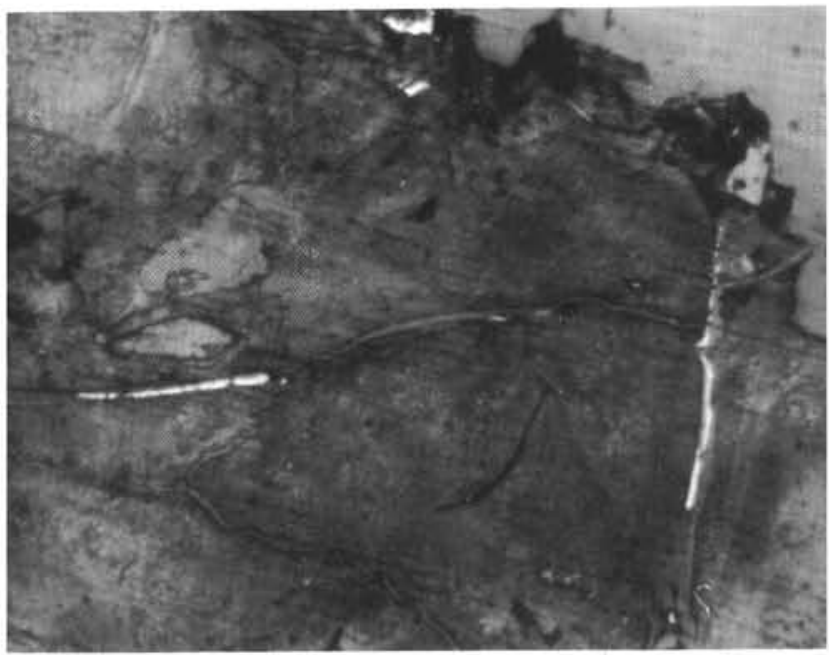

Figure 18. Silicate glass, altered to smectite, veined by pyrite. Sample 428A-5-3, $123-126 \mathrm{~cm}$; reflected and transmitted light, $\times 16$.

phases exists in the spheres. Pyrite is the only recognizable sulfide.

The five uppermost polished sections are oxidized and altered. Groundmass minerals, feldspar, and glass were replaced by these oxides and calcite. The opaques in these areas are apparently oxidized; rim staining surrounds remnant Ti-magnetites. Small sulfides veinlets appear to have been emplaced after the oxidation and cross-cut other secondary minerals as in Holes 428 and 428A (e.g., clays and chlorite). Some of the iron oxyhydroxides are crystallized into hematite and goethite 
which are evident in the polished samples (Figure 19). $\mathrm{Cr}$-spinel is present as 5 to $10-\mu \mathrm{m}$ euhedral crystals in one glassy sample (Figure 20).

Ti-magnetites dominate the opaques in size and overall abundance. The morphology of these oxides is generally skeletal-dendritic to skeletal-subhedral. The individual crystal size within a particular sample is proportional to the degree of undercooling. The first six samples (from the top of the core downward) were quickly quenched, and thus the size of the Ti-magnetites is small - generally $10 \mu \mathrm{m}$ to $15 \mu \mathrm{m}$. The basalts comprising the lower samples obviously were allowed to cool more slowly and the Ti-magnetites average about $25 \mu \mathrm{m}$ in diameter.

\section{Descriptive Mineralogy}

\section{Titanomagnetites}

The dominant opaque in volume $(<1 \%$ to $\leq 6 \%)$ and size in all of the basalts was found to be Timagnetite. These oxides vary from subhedral grains less than $1 \mu \mathrm{m}$ in diameter, through an entire size range and various morphologies, to euhedral tetrahedra of diameters greater than $100 \mu \mathrm{m}$. As previously stated, microprobe analyses indicate a composition of $(0.38$ to $\left.0.4 \mathrm{Fe}_{3} \mathrm{O}_{4}\right)\left(0.6\right.$ to $\left.0.62 \mathrm{FeTiO}_{2}\right)$. This formula approximates the composition reported by Ade-Hall et al. (1976) for the same phase in DSDP basalts from the Nazca plate.

The size and crystal morphology of the Ti-magnetites appear to have been governed by the extent of supercooling of the melt. The basalt samples containing clinopyroxene and plagioclase mosaics as the groundmass apparently have cooled relatively slowly. The Timagnetites in these basalts are large $(25$ to $100 \mathrm{~m}$ in diameter) subhedral to euhedral crystals. The degree of

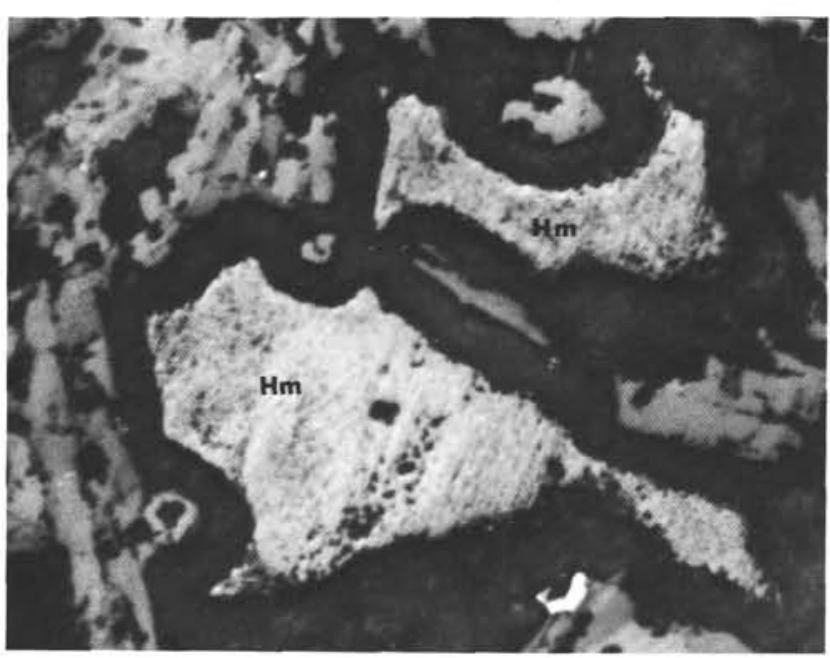

Figure 19. Irregular replacement of silicate glass by hematite (in core) and smectite/amorphous iron oxides (darker rim). Sample 429A-4-1, 45-47 cm; reflected light $\times 8 . \mathrm{Hm}=$ hematite.

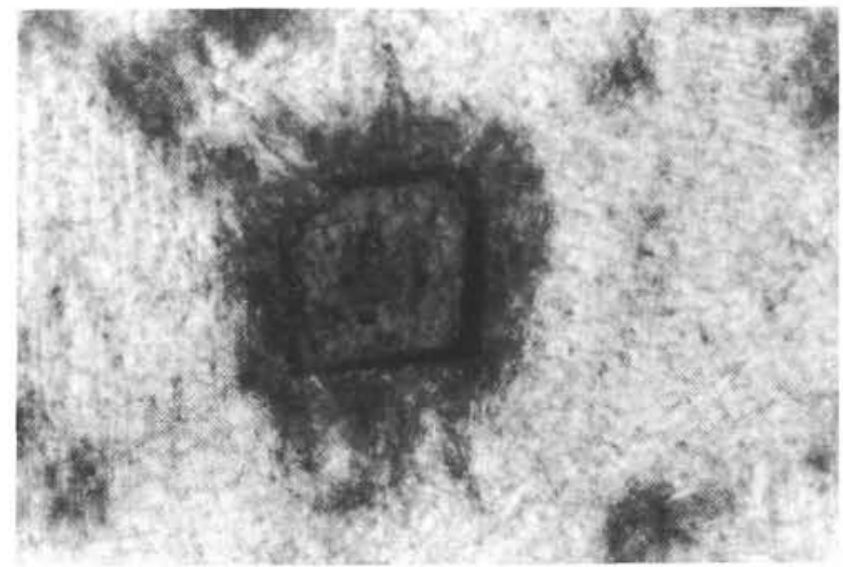

Figure 20. Cr-spinel, surrounded by devitrified halo, floating in a glassy matrix. Sample 429A-2-1, 9-11 $\mathrm{cm}$; transmitted light, $\times 8$.

skeletal development in these crystals may be a function of cooling (e.g., crystallization), time, and the availability of chemical constituents in the proximal melt. The glassy basalt samples contain very small $(<5 \mu \mathrm{m}$ in diameter) and morphologically diverse Ti-magnetites. Multiply twinned, skeletal tetrahedra are common. Sizes may be as small as $0.5 \mu \mathrm{m}$ in diameter. Abundance is directly proportional to size. Samples that consist totally of glass have no primary oxides at all. These samples do not, however, differ in bulk $\mathrm{TiO}_{2}$ and total $\mathrm{FeO}$ content from more crystalline adjacent samples. Thus, the necessary metallic constituents were available for crystallization of Ti-magnetites. Two limiting factors may have inhibited the growth of these oxides:

(1) Insufficient time for nucleation and growth due to rapid chilling of melt (we have shown that these oxides are among the final phases to crystallize); and

(2) Degassing of the rapidly cooling melt has left insufficient oxygen for the oxidation of the metals dissolved in the silicate melt.

Very little oxidation or secondary alteration of the magnetites was observed in the samples studied. In no sample was oxidation common. This evidence leads us to the same conclusion as postulated by Grommé et al. (1969); the short period between eruption and sampling has precluded extensive secondary reactions.

Deuteric alteration in the form of ilmenite exsolution was observed in six samples. These occurrences are significant, since this phenomenon is not common in subaqueously erupted tholeiites (Kitazawa and Ade-Hall, 1972). No correlation exists between the abundance of cracks and ilmenite lamellae as reported by Ade-Hall et al. (1976). However, the ilmenite occurs in basalt that is more vesiculated than surrounding samples. This relationship suggests that the evolution of certain magmatic gases (such as hydrogen) favored the oxidation of the primary Ti-magnetites. The removal of $\mathrm{H}$ and $\mathrm{OH}$ by vesiculation would produce a localized environment favoring oxidation reactions in the remaining melt (Sato and Wright, 1966; and Ade-Hall et al., 1976). 


\section{Cr-Spinel}

These minerals were seen in only a few samples (Table 1); however, the presence of this phase has significant ramifications. The oxides typically occur in more primitive basalts than those retrieved on Leg 54 (Schrader et al., 1977).

The spinels are optically and chemically similar to those in picritic basalts from the Siqueiros transform fault. The crystals are euhedral to subhedral, showing no evidence of physical abrasion; however, some resorption has occurred at the juncture of crystal faces (Figure 20). In transmitted light the spinels are orangered; in reflected light they appear tan to grey. Sizes range from $5 \mu \mathrm{m}$ to $25 \mu \mathrm{m}$ in diameter.

The spinels in these basalts are probably xenocrysts from more mafic magmas. Spinels, orthopyroxenes, and Mg-rich olivines are typical of cumulate assemblages in the near-static magma reservoirs beneath active transform faults (Schrader et al., Picritic basalts etc., this volume). Thus, spinels and other dense phases present in evolved basalts cored or dredged from rise crests may indicate the influence of transform faults or other through-going structures on magmatic ascent. Deeply penetrating structures may tap primitive magmas which evolve during ascent, retaining spinel xenocrysts.

\section{Ilmenite}

The presence of ilmenite was restricted to a few deuterically altered Ti-magnetites, except in Sample 420-14-1, 10-17 cm. This specimen has a few ilmenite blades clustered around a large vesicle. The orientation of the blades is radial to the gas bubble. This spatial relationship was probably generated and controlled by the rapid evolution of gases during vesiculation. The streaming of hydrogen out of the immediate area surrounding the vesicle created a micro-environment that was sufficiently oxidizing for ilmenite to form. After vesiculation and ilmenite crystallization, small Ti-magnetites nucleated and grew in the same area but were not oxidized.

\section{Iron Oxides}

Amorphous-hydrated iron oxides, goethite, and hematite were identified in samples of basalt retrieved on Leg 54. Apparently the hematite was dehydrated from either goethite or amorphous iron oxides. The hematite generally occurs as the central portion of a vesicle filling or as the core of a pocket of silicate glass altered to clay and amorphous iron oxide.

The iron oxides were generated in two distinct environments. Some vesicles and other open spaces were filled or coated with amorphous or finely crystallized hydrated iron oxides (Figure 21). These coatings probably precipitated from seawater reacting with surrounding basalts or from diluted and cooled hydrothermal fluids. No alteration of silicate phases is associated with these oxides.

As previously discussed, another class of iron oxides occurs only in veins that are associated with alteration of the silicate phases. Often these oxides are associated

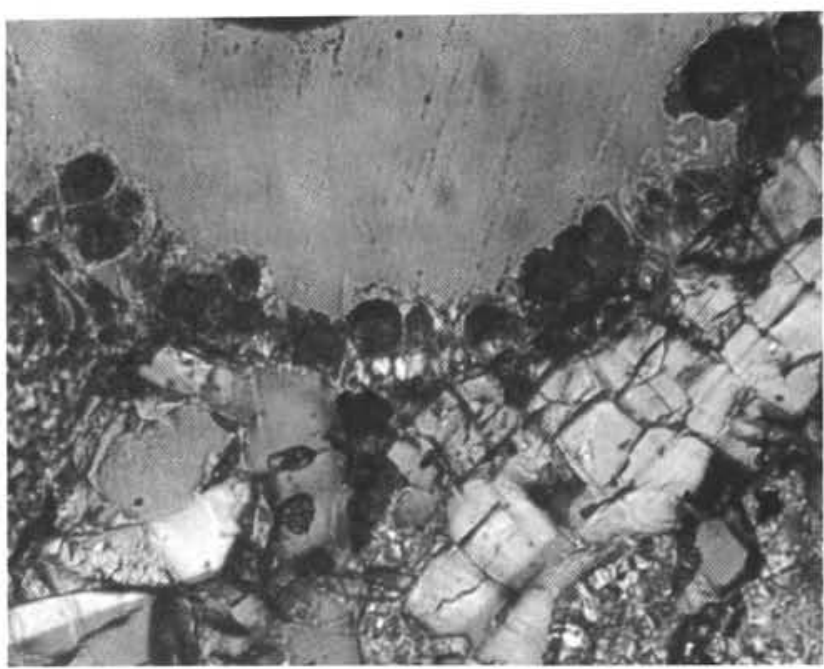

Figure 21. Amorphous iron-manganese oxides lining wall of an empty vesicle. Sample 424C-2-1 (Piece 7). Transmitted light; $\times 16$.

with euhedral to subhedral, secondary pyrite crystals. Glass and olivine are two phases that appear to be selectively altered to clay, sulfide, and iron oxide (Figure 22). Associated with the alteration of glass and olivine to layer lattice silicates is the replacement of feldspar (and surrounding glass) by low-Mg calcite. Since this form of calcite does not directly precipitate from sea water (Ronald D. Perkins, personal communication), the mechanism generating this style of alteration must be either deuteric alteration/hydration or secondary hydrothermal interaction with the basalt.

\section{Sulfides}

Two major periods of sulfide deposition occurred in the basalts retrieved on Leg 54:

1) Primary - globular segregations and crystal euhedra; and,

2) Secondary - veins and disseminated crystals in an altered matrix.

The primary sulfides appear to have crystallized directly from the silicate melt. Sulfide spheres, similar to those described by Mathez and Yeats (1976), and Moore and Calk (1971), are present in a majority of the samples and constitute volumetrically 80 to 85 per cent of all the sulfides in all samples. Pyrite is by far the dominant mineral phase in these spheres. Chalcopyrite, $\mathrm{Co}-\mathrm{Ni}$ phases (probably pentlandite and cobaltite) and pyrrhotite also occur in the sulfide globules. Approximately 80 per cent of the spheres are monomineralic, being composed of only pyrite. The remainder consist of a variety of assemblages (e.g., pyrite-chalcopyrite; pyrite-pyrrhotite; pyrite-pyrrhotite-(Co, Ni) phase; pyrrhotite-chalcopyrite). The phases are intimately intergrown and exhibit textures typical of mutual exsolution. Flame-like exsolution textures in the pyrrhotite are similar to pentlandite-pyrrhotite intergrowths which occur in various Canadian Co-Ni ore deposits (Stanton, 1972). Since most of the exsolved phases are from 1 to 


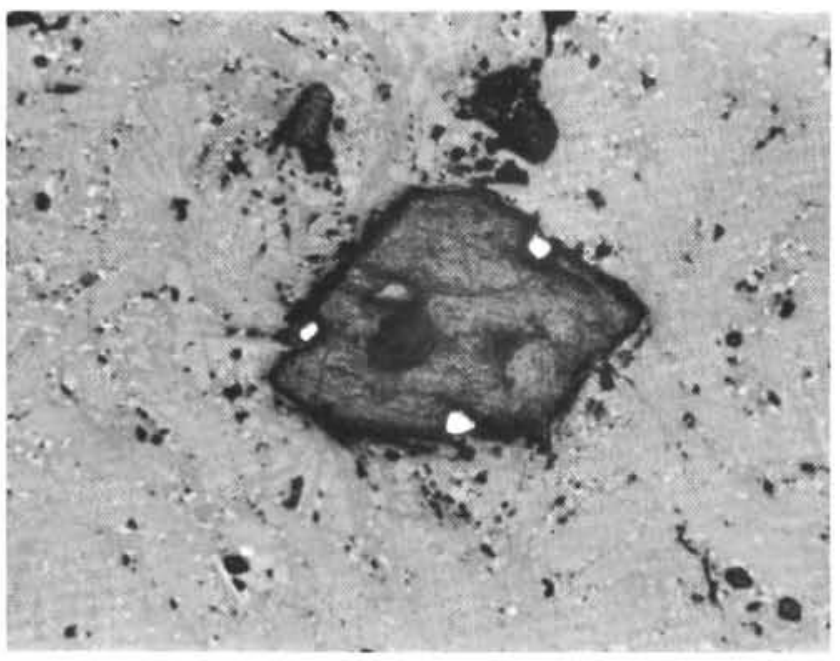

Figure 22. Replacement of olivine phenocryst by smectite (core), pyrite (high reflectivity mineral) and iron oxide (dark lining between matrix and pseudomorph). Sample 421-4-1, 32-36; reflected light; $\times 8$.

$0.5 \mu \mathrm{m}$ in width, microprobe analyses were not accurate or reproducible.

The secondary sulfides are presumed to have been hydrothermal and/or deuteric processes. Most of the sulfide veining consists of pyrite. In a few veins, pyrite is accompanied by pyrrhotite and chalcopyrite segregations. No Co-Ni phases occur as vein fillings. The subsidiary phases are not exsolved from the pyrite as in the spheres but occur as small $(1=\mu \mathrm{m})$ blebs floating in the larger pyrite masses, suggesting a low-temperature sulfide immiscibility.

Sulfide veins replace silicates and Ti-magnetite. Additionally, primary or deuteric sulfide accumulations appear to have replaced some of the feldspar phenocrysts during crystallization of the melt.

\section{SPECULATIONS ON ORE DEPOSITS FORMED AT TRAILING PLATE EDGES}

Axial magma reservoirs at active spreading centers offer a greater variety of tectonic and physicochemical settings for the emplacement of ores than many other environments. The variety of ore deposits that could theoretically be formed within this tectonic regime is quite diverse; however, from our observations and previously documented chemical affinities, only a few types of ore deposits should be expected to occur regularly at trailing plate edges. Some of these deposites are:

(1) Disseminated copper sulfides and massive sulfides;

(2) Chromite and magnetite pods or zones in stratiform mafic and ultramafic complexes;

(3) $\mathrm{Co}-\mathrm{Ni}-\mathrm{Cu}$ sulfide vein systems; and

(4) Bedded iron-manganese oxides.

\section{Disseminated Copper Sulfides and Massive Sulfides}

Disseminated copper deposits are distinguished from typical "massive sulfide" ore systems in that the major zone of ore formation comprises tiny veinlets $-\sim 5$ $\mathrm{mm}$ wide (ore stringers), mineralizing the parent intrusion or country rock. There is no central mass of chemically precipitated sulfide ore below the stringer zone as seen in massive sulfides. The sulfide ores associated with the ultramafic sequence on Cyprus have been described erroneously as disseminated sulfides, whereas they actually represent small volcanogenic massive sulfide systems (personal communication, M. J. Holtzclaw, Chevron Resources Company).

Although Bonatti et al. (1977) suggested that portions of the Mid-Atlantic Ridge might lie above disseminated sulfide deposits, the total weight of evidence is against such a possibility. Disseminated copper sulfide systems have a marked preference for intermediate to silicic volcanics (andesites to alkali-rhyolites) (Sillitoe, 1973; Lowell and Guilbert, 1970; and Wallace et al., 1968). The mineralized veins are usually dominated by free-quartz, late-stage, volatile-containing minerals (topaz, fluorite), and $\mathrm{Fe}-\mathrm{Cu}-\mathrm{Mo}$ sulfides. Nickel and copper are usually lacking in these ores (Stanton, 1972). Additionally, the host intrusions for such mineralization are thought to have vented subaerially (Sillitoe, 1973). The pressure constraints associated with the venting are apparently important in the deposition of orebearing phases.

The source of mineralization is not primary magmatic or deuteric fluids. Rather, the sulfides are generally thought to be transported by cyclic meteoric systems (formed as a result of caldera subsidence) that interact with intrusions and wall rock. Ring fractures bordering calderas localize and focus these reactive solutions in low-grade disseminated sulfide deposits.

Along rise crests, the major structural features tend to parallel the spreading center and generally give way to through-going features such as axial grabens (or horsts) and transforms (Rosendahl et al., 1976). Instead of focusing and providing a locus for mineralizing fluids, these features would tend to disperse and dilute such solutions except in special cases (Rona, 1978).

The location of the mounds hydrothermal field near the Galapagos spreading center indicates the downward movement of cold sea water nearer the rise crest (Lonsdale, 1977). Heated reactive sea water then migrates away from the crest along fissures and ascends at the site of the iron-manganese oxide mounds. This suggested path of fluid flow is opposite to that described by Bonatti (1978).

Although the formation of disseminated sulfides as described here is not yet recognized at rise crests, the same processes invoked for this type of deposition could in unusual circumstances be effective in transportation and localization of metal and sulfate ions on a large enough scale to produce typical massive sulfide deposits. In general, massive sulfide systems are thought to be associated with two tectonic regimes: (1) subduction and back arc spreading-related vulcanism (Urabe and Sato, 1978); and (2) incipient and aborted rift systems with restricted sea-water circulation (Campbell et al., 1978). Since massive sulfide deposits usually replace, and intercalate with, laterally contemporaneous marine and/or pyroclastic sediments, the rise crest is not an ideal en- 
vironment for their formation. The sediment blanket is thin and the crust is being constantly moved away from the locus of hydrothermal activity. This explanation runs parallel to that espoused by Lonsdale (1977) for the lack of hydrothermal deposits along the axis of the Galapagos rift system. More plausible tectonic settings for disseminated sulfide deposits are related to, and partially responsible for, the development of high-rank magmatic differentiation suites associated with island arc chains and volcanic seamounts. These settings demand static volcanic systems.

The processes of island arc vulcanism and magmatic evolution beneath seamounts are longer lived and geochemically more efficient in volatile concentration than the upwelling of basalts near rise crests. Although massive and disseminated sulfide formation is not precluded at spreading centers, other environments appear more receptive.

\section{Stratiform Deposits}

The ultimate source and the causes of rhythmic layering in large layered deposits of chromite, magnetite, pyroxenite, and anorthosite (such as the Bushveld and Transvaal Complexes in Rhodesia and the Stillwater Complex in the United States) have long been discussed. The near steady-state nature of an axial rise crest magma chamber as described by Rosendahl et al. (1976) would offer an excellent environment for the evolution of such layered sequences; these might contain, for example, podiform chromite deposits (Thayer, 1964).

Rosendahl et al. (1976) proposed that such a reservoir underlies the East Pacific Rise near the Siqueiros transform fault. The seismic data indicated systematic variation within the magma chamber, corresponding to less dense layers toward the top and more dense layers near the base. Actual dimensions of the chamber were not derived.

Hodges and Papike (1976) recognized the efficiency of cumulus processes in forming gabbros and peridotites retrieved at DSDP Site 334. Their data indicate a long period of slow crystal accumulation and cooling beneath an Atlantic spreading center.

Several samples retrieved on Leg 54 contain olivine and spinel chemically and mineralogically similar to picrites of the Siqueiros fault zone. Schrader et al. (1977) and Schrader et al. (Picrites, etc., this volume) have suggested that picritic basalts dredged from the Siqueiros fracture were erupted from an intermediate to deep zone within the axial magma chamber. This zone would lie between the less dense (feldspar-rich) and more dense (olivine and pyroxene-rich) regions comprising the reservoir stratigraphy. The olivine, orthopyroxene, and spinel contents of the Siqueiros picrites may indicate mineral segregation by gravity settling of these dense phases. Thus, eruptive basalts with unusually high concentrations of these as cumulus minerals may indicate incipient gravitative differentiation that has occurred in such stratified magma reservoirs (see Figure 23).

Since the axial reservoirs are intersected by central graben (or horst) faults and penetrated by cross-cutting faults in the Siqueiros transform system, a variety of

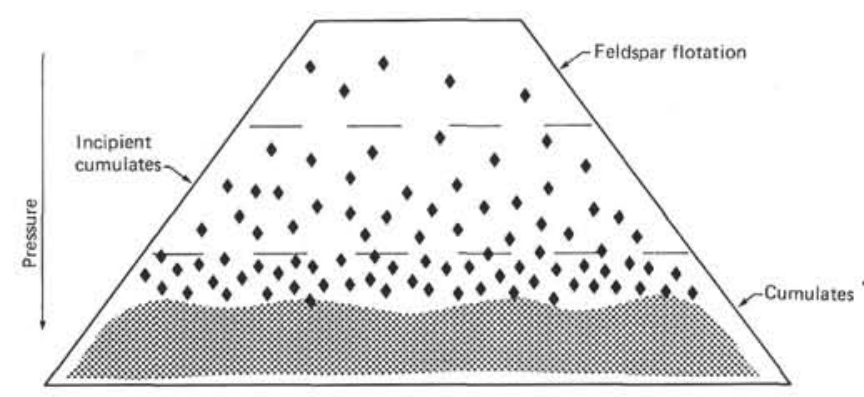

Figure 23. Diagrammatic cross section through magma chamber underlying the East Pacific Rise as described by Rosendahl et al. (1976). Seismic response indicated: a less dense layer near the apex, corresponding to flotation of feldspar in a silicate melt, an intermediate density zone, and a dense layer near the base (perhaps lower in melt content). We posit that the segregations are due to gravitative response of more dense phases (olivine, spinel, orthopyroxene) and, thus, their cumulation at the base. Black diamonds in the figure represent cumulate phases and their relative abundance in the various density zones as defined by seismic investigations.

controls are available to create rhythmic banding. The continued but sporadic movement along transform faults could be the control needed to induce repetitive magma pulses within the affected magma chamber. Such faults also allow cooling sea water access to the deep crust. The mineral phases crystallizing within a magma at any one instant could then be related to the amount of time (coincident with strain accumulation along such faults) that the magma has resided in the chamber, and the loss of heat that it has therefore experienced, since its previous pulse of magma. Longer residence periods would allow greater accumulation of dense silicate phases and related ores which would be laterally accreted as oceanic Layer 3. Repetitive pulses of primitive magma would restrict cryptic variation (Wager, 1968), perhaps allowing rhythmic repetition of olivine- and chromite-rich layers.

\section{Co-Ni-Cu Sulfide Veins}

In samples of basalt retrieved during Leg 54 no veins containing $\mathrm{Ni}$ or Co sulfides were recognized; however, these metals were seen to be common constituents of the sulfide spheres dispersed in the glass matrix of many samples. The average crustal concentration of $\mathrm{Co}$ and $\mathrm{Ni}$ ( 25 and $75 \mathrm{ppm}$, respectively) is significantly below the average concentrations of these cations in basalts (Co $=48 \mathrm{ppm}, \mathrm{Ni}=150 \mathrm{ppm})$ (Krauskoph, 1967). It is obvious that the ongoing processes of magmatic evolution which occur near the East Pacific Rise (Batiza et al., 1977) may cause these "incompatible" metals to become residually concentrated in highly differentiated basalts or released into a coexisting brine during crystallization of the basalt. Additionally, McBirney and Williams (1969) have shown that these trace constituents could be concentrated by magmatic hybridization of a tholeiitic basalt. The alkaline basalts and other effusive 
rocks described from the Galapagos Islands (McBirney and Williams, 1969) in several cases are significantly enriched in $\mathrm{Co}, \mathrm{Ni}$, and $\mathrm{Cu}$ over the relatively more primitive basalts in the vicinity.

Known ore deposits comprising Co-Ni sulfides are frequently associated with slightly hybridized or fractionally evolved mafic suites. Examples include the associations of noritic gabbros (Sudbury, Ontario), ultramafics (Lynn Lake, Manitoba), and diabases (Cobalt, Ontario).

Variations in the generally static condition of magma reservoirs underlying the East Pacific Rise could induce types of basalt hybridization similar to those associated with the forementioned deposits. If the magma chamber is isolated from a continual source of replenishing melt from the mantle, evolution of the remaining melt would proceed along lines favoring production of a volatilerich, incompatible metal-rich, and alkali-rich residual melt. This isolation could allow the systematic concentration of these trace constituents in a brine phase which is evolved during final cooling and solidification. Such a fluid, migrating through fissures and cracks generated by cooling contractions, would serve as a mineralizing source for the basalt and surrounding strata. The occurrence of such evolved sequences of basalts and basaltic differentiates is common in the seamounts, volcanic islands, and sea-floor ridges of the eastern Pacific.

A variety of Canadian and Mediterranean cobaltnickel sulfide deposits occur in greenstone belts. Soviet geologists (Yuri Bilibin and others) in the mid-1940's recognized these belts as remnant "mobile" zones. We now interpret these belts as possible plate junctures and fossil spreading centers. Thus the environments of oceanic vulcanism associated with divergent plate margins are possibly the setting for localization of such cobaltnickel vein systems.

\section{Bedded Iron-Manganese Deposits}

Iron-manganese deposits of the mounds hydrothermal field were sampled during Leg 54. These deposits are being actively formed adjacent to the Galapagos rift.

The mounds hydrothermal field was discovered during a deep-tow survey south of the Galapagos rift in 1972 (Klitgord and Mudie, 1974), and was subsequently studied in detail during a second deep-tow survey (Lonsdale, 1977). The mounds are conical in section and elongate in plan and are arranged in parallel chains of 1 to $2 \mathrm{~km}$ in length. Lonsdale (1977) also states that the mound chains overlie small bedrock faults and fissures. $\mathrm{He}$ suggests that these openings are the channels for ascending hydrothermal fluids which are responsible for the oxide deposition.

The general basement structure in the area of the mounds comprises normal faults dipping northward toward the base of the spreading center (Klitgord and Mudie, 1974). These faults give rise to low-relief abyssal hills and valleys parallel to the axis of the major rift system.

Preliminary, shipboard XRF whole-rock analyses of the basement basalts recovered on Leg 54 showed them to be highly fractionated, Fe-rich tholeiites $\left(\mathrm{SiO}_{2} \sim\right.$ $51 \% ; \mathrm{Al}_{2} \mathrm{O}_{3} \sim 13.5 \% ; \mathrm{FeO}^{* 2} \sim 14.2 \% ; \mathrm{MgO} \sim 4.8 \%$; and, $\mathrm{CaO} \sim 10.4 \%$ ). The cored samples comprise fineto coarse-grained plagioclase and clinopyroxene basalts. Glassy margins are rare, and cooling units can only be estimated by grain size variations.

The general megascopic appearance is one of fresh, fine-grained basalts with $1-$ to $2-\mathrm{cm}$ alteration rinds adjacent to fractures and joint surfaces. Vesicles can be seen to be filled with blue-green clay minerals, iron oxides, and calcite. Needle-like crystals, perhaps zeolites, are also present in a few small $(\sim 1-\mathrm{mm})$ vesicles.

Two mounds were drilled as well as a reference section between them. The recovered sediment cores consisted of interbedded $\mathrm{Fe}-\mathrm{Mn}$-rich zones and calcareous, foraminifer-nannofossil ooze. The Fe-Mn zones dominate the upper 20 meters of core and cap the mound surfaces. The metal oxides appear amorphous upon microscopic examination (Figure 24).

It has been reported that many of the bedded manganese ore deposits are associated, perhaps accidentally, with volcanic activity (Hewitt, 1966). Many occurrences of this type of ore contain various amounts of volcanic ash and other debris (Stanton, 1972).

The conspicuous occurrence of manganese ores with carbonates and the low concentration of iron in many manganese ores can be explained by this sea floor, effusive hypothesis. The interbedded siliceous carbonate units in manganese ore deposits might correspond to the diatom-bearing carbonate oozes lateral to the deposits. The efficiency of sea-floor hydrothermal systems to concentrate manganese relative to iron is well documented (Hekinian, Rosendahl et al., 1978).

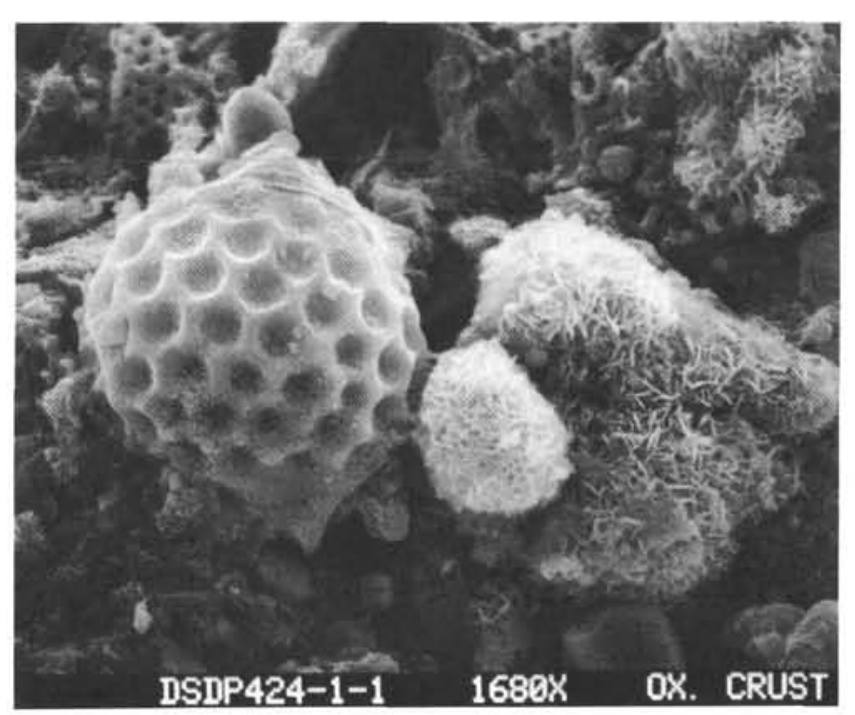

Figure 24. Amorphous manganese oxides at sediment/ water interface of Hole 424. Oxides are the platy aggregates. Recent fossils comprise the remainder of the sample. Sample 424-1-1, 1-2 cm; scanning electron micrograph; $\times 1680$.

\footnotetext{
${ }^{2}$ Expressing total iron content.
} 
Chemical analyses of the mud and oxides/hydroxides comprising the mounds are reported in another chapter of this volume (see Schrader et al., Geochemistry of sediments).

These bedded, volcanogenic manganese oxide deposits may be analogs to such deposits as the manganese beds in Central Kazakhstan, Russia (Shatsky, 1964) which contain up to 20 per cent $\mathrm{Mn}$ intercalated with silica-rich layers and pseudomorphs after carbonate minerals. Further study of the chemistry, mineralogy, and modes of deposition of these deposits in future DSDP cruises is certainly warranted.

\section{CONCLUSIONS}

A variety of ore minerals are present in tholeiites of the eastern Pacific. Both primary magmatic and secondary ore minerals occupy open spaces and replace the silicate phases of the basalts. The opaque phases are dominated by titanium-rich magnetites with subordinate pyrite. Sulfides occur as magmatic segregations and in hydrothermally deposited veins. Some ore deposits that are typically associated with diabases, greenstone belts, and ultramafics were likely formed at oceanic spreading centers. Three types of deposits seem to be at least circumstantially indicated by the minerals and textures observed in the samples studied. These deposits are:

1) Stratiform (cumulate) complexes;

2) Vein-type $\mathrm{Ni}-\mathrm{Co} \pm \mathrm{Cu}$ systems; and,

3) Bedded manganese oxides.

\section{ACKNOWLEDGMENT}

The authors gratefully acknowledge critical review of this manuscript and stimulating discussions offered by Dr. M. A. Goldstein, Chevron Resources Company, Denver, Colorado.

\section{REFERENCES}

Ade-Hall, J. M., Fink, L. K., and Johnson, H. P., Petrography of opaque minerals, Leg 34. In Yeats, R. S., Hart, S. R., et al., 1976. Initial Reports of the Deep Sea Drilling Project, v. 34: Washington (U. S. Government Printing Office), p. 349-362.

Batiza, R., Rosendahl, B. R., and Fisher, R. L., 1977, Evolution of oceanic crust 3. Petrology and chemistry of basalts from the East Pacific Rise and Siqueiros transform fault. $J$. Geophys. Res., v. 82 , p. $265-276$.

Bonatti, E., Guerstein-Honnorez, B. M., and Honnorez, J., 1976. Copper-iron sulfides mineralizations from the equatorial Mid-Atlantic Ridge. Econ. Geol., v. 71, p. 15151525.

Bonatti E., 1978, The origin of metal deposits in the oceanic lithosphere. Sci. Am., v. 238, p. 54-61.

Campbell, F. A., Ethier, V. G., Krouse, H. R., and Both, R. A., 1978. Isotopic composition of sulfur in the Sullivan orebody, British Columbia. Econ. Geol., v. 73, p. 246-268.

Grommé, C. S., Wright, T. L., and Peck, D. L., 1969. Magnetic properties and oxidation of iron-titanium oxides in Alae and Makaophui Lava Lakes, Hawaii. J. Geophys. Res., v. 74, p. 5277-5294.

Hekinian, R., Rosendahl, B. R., Cronan, D. S., Dimetriev, Y., Fodor, R., Goll, R. M., Hoffert, M., Humphris, S. E., Mattey, D. P., Natland, J., Petersen, N., Schrader, E. L.,
Srivastava, R. K., and Warren, N., 1978. Hydrothermal deposits and associated basement rocks from the Galapagos spreading center. Oceanologica Acta, v. 1, p. 473-482.

Hewitt, D. F., 1966, Stratified deposits of the oxides and carbonates of manganese. Econ. Geol., v. 61, p. 431-461.

Hodges, F. N. and Papike, J. J., 1976. DSDP Site 334: Magmatic cumulates from oceanic Layer 3. J. Geophys. Res., v. 81 , p. $4135-4151$.

Keays, R. R. and Scott, R. B., 1976. Precious metals in oceanridge basalts: Implications for basalt as source rocks for gold mineralization. Econ. Geol., v. 71, p. 705-720.

Kitazawa, K. and Ade-Hall, J. M., 1972. Magnetic and opaque mineralogical properties of basalts from DSDP Legs II, III, V, and VI. Am. Geoph. Union Trans., v. 53, p. 974 (Abstract).

Klitgord, K. D. and Mudie, J. D., 1974. The Galapagos spreading centre: A near-bottom geophysical survey. Geophys. J. R. Astron. Soc., v. 38, p. 563-586.

Krauskopf, K. B., 1967. Geochemistry: New York (McGrawHill).

Lonsdale, P., 1977. Deep-tow observations at the mounds hydrothermal field, Galapagos Rift. Earth Planet. Sci. Lett., v. 36, p. 92-110.

Lowell, J. D. and Guilbert, J. M., 1970. Lateral and vertical alteration-mineralization zoning in porphyry ore deposits. Econ. Geol., v. 65, p. 373-408.

Mathez, E. A. and Yeats, R. S., 1976. Magmatic sulfides in basalt glass from DSDP Hole 319A and Site 320, Nazca Plate. In Yeats, R. S., Hart, S. R., et al., Initial Reports of the Deep Sea Drilling Project, v. 34: Washington (U. S. Government Printing Office), p. 363-374.

McBirney, A. R. and Williams, H., 1969. Geology and petrology of the Galapagos Islands. Geol. Soc. Amer. Memoir, v. 118 , p. 192.

Moore, J. G. and Calk, L., 1971. Sulfide spherules in vesicles of dredged pillow basalt. Am. Mineralogist, v. 56, p. 476488.

Rona, P. A., 1977. Criteria for recognition of hydrothermal mineral deposits in oceanic crust. Econ. Geol., v. 73, p. $135-160$.

Rosendahl, B. R., Raitt, R. W., Dorman, L. M., Bibee, L. D., Hussong, D. M., and Sutton, G. H., 1976. Evolution of oceanic crust, 1, A geophysical model of the East Pacific Rise crest derived from seismic refractions data. J. Geophys. Res., v. 78, p. 5294-5304.

Sato, M. and Wright, T. L., 1968. Oxygen fugacities directly measured in magmatic gases. Science, v. 153, p. 1103-1105.

Schrader, E. L. and Furbish, W. J., 1976. Correlations of uranium and trace metal concentrations in mineralized rhyolites from Nevada. Geol. Soc. Am. Abstracts, v. 8, p. 1089-1090.

Schrader, E. L., Rosendahl, B. R., and Furbish, W. J., 1977, Primative Picrites from the Siqueiros Fracture Zone, East Pacific Rise. Ibid., v. 9, p. 1162.

Shatsky, N. S., 1964. On manganiferous formations and the metallogeny of manganese, Paper I. Volcanogenic-sedimentary manganiferous formations. Int. Geol. Rev., v. 6, p. $1030-1056$.

Sillitoe, R., 1973. The tops and bottoms of porphyry copper deposits. Econ. Geol., v. 68 , p. $799-815$

Stanton, R. L., 1972. Ore Petrology, New York (McGrawHill).

Thayer, T. P., 1964. Principal features and origin of podiform chromite deposits, and some observations on the GulemanSoridag district, Turkey. Econ. Geol., v. 59, p. 1497-1524.

Urabe, T. and Sato, T., 1978. Kuroko deposits of the Kosaka Mine, Northeast Honshu, Japan-Products of submarine 
hot springs on Miocene sea floor. Econ. Geol., v. 73, p. 161-179.

Wager, L. R., 1968. Rhythmic and cryptic layering in mafic and ultramafic plutons. In Hess, H. H. and Poldervaart, A. (Eds.), Basalts: New York (Wiley Interscience), v. 2, p. 573-622.
Wallace, S. R., Muncaster, N. K., Janson, D. C., McKenzie, W. B., Bookstrom, A. A., and Surface, V. E., 1968. Multiple intrusion and mineralization at Climax, Colorado. In Ridge, J.E. (Ed.), Ore Deposits of the United States, 19331967: Am. Inst. Mining Metall. Petroleum Engnrs., v. 1, p. $605-640$. 